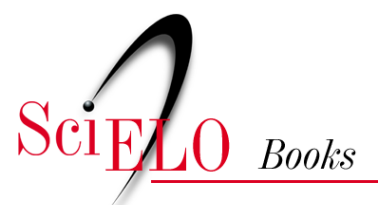

\title{
5 - Estudos sobre a doença de Chagas Researching Chagas disease
}

\author{
Simone Petraglia Kropf \\ Aline Lopes de Lacerda \\ Diane Grosklaus Whitty (trad.)
}

\section{SciELO Books / SciELO Livros / SciELO Libros}

KROPF, S.P., and LACERDA, A.L. Estudos sobre a doença de Chagas = Researching Chagas disease. In: Carlos Chagas, um cientista do Brasil = Carlos Chagas, scientist of Brazil [online]. Translated by Diane Grosklaus Whitty. Rio de Janeiro: Editora FIOCRUZ, 2009, pp. 106-147. ISBN: 978-65-5708-000-9. https://doi.org/10.7476/9786557080009.0009. \section{International license.}

All the contents of this work, except where otherwise noted, is licensed under a Creative Commons Attribution 4.0

Todo o conteúdo deste trabalho, exceto quando houver ressalva, é publicado sob a licença Creative Commons Atribição $\underline{4.0}$. 


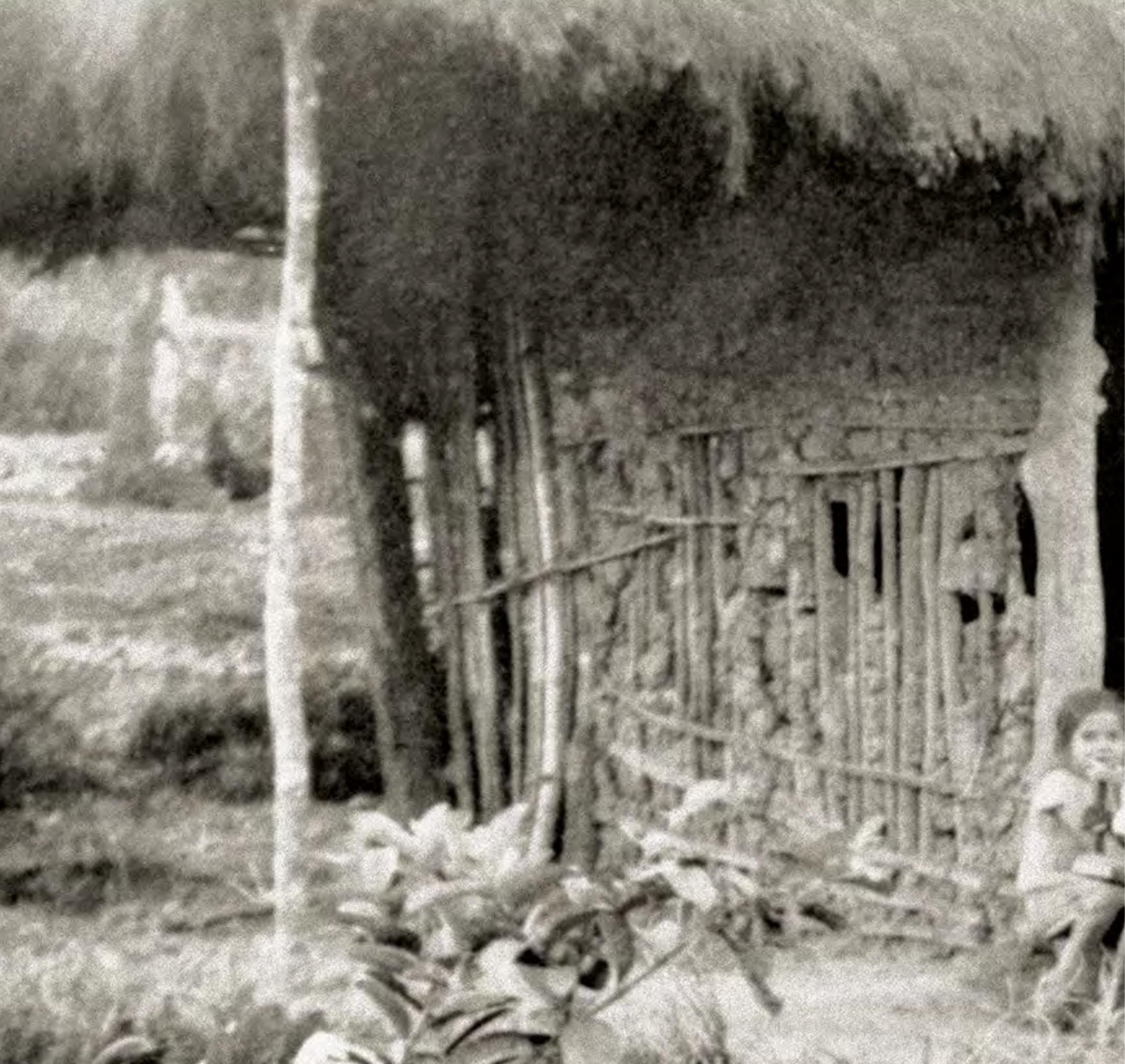

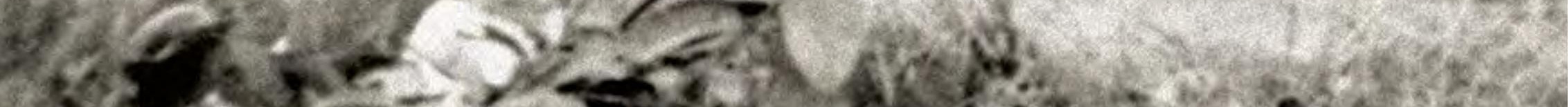

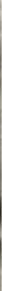




\section{Estudos sobre a doença de Chagas Researching Chagas disease}

(s)

\section{nownty}

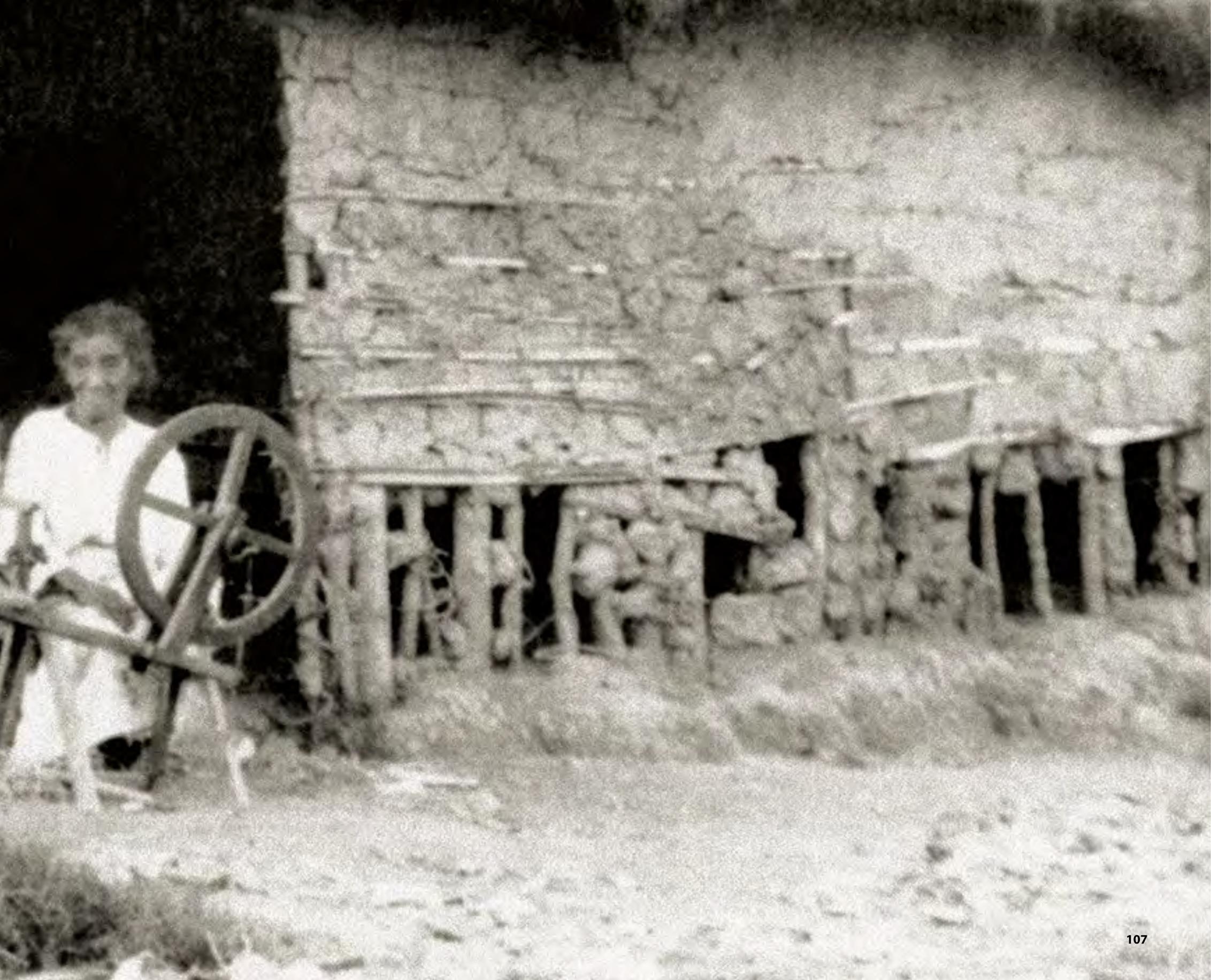


A doença de Chagas tornou-se um dos principais temas na agenda de investigação do Instituto Oswaldo Cruz. Com a colaboração de outros pesquisadores, Carlos Chagas dedicou-se a estudá-la em seus vários aspectos: as características biológicas do vetor e do parasito, os reservatórios do Trypanosoma cruzi, as manifestações clínicas e a evolução da doença, os métodos de diagnóstico e possíveis formas de terapêutica.

Seus trabalhos sobre a doença foram apresentados nas principais associações médicas do país. Em 1911, na Exposição Internacional de Higiene e Demografia, em Dresden, Alemanha, a nova enfermidade despertou grande interesse. Em 1912, Chagas recebeu do Instituto de Doenças Marítimas e Tropicais de Hamburgo o Prêmio Schaudinn de protozoologia. No ano seguinte, foi indicado ao Prêmio Nobel de Medicina. Na época, o governo federal garantiu recursos para a construção, em Lassance e em Manguinhos, de hospitais destinados a investigar a doença.

Segundo os primeiros estudos de Chagas, o período inicial da infecção pelo T. cruzi tinha como principais sintomas febre, aumento do fígado, do baço e dos gânglios, e inchaço no rosto indicativo de comprometimento tireoidiano. Chagas dividiu a fase aguda em duas formas: casos com graves distúrbios cerebrais (geralmente crianças com menos de 1 ano, que quase nunca sobreviviam) e casos mais frequentes, sem tais manifestações, que logo evoluíam para o estado crônico.

$\mathrm{Na}$ fase crônica, haveria distúrbios endócrinos, cardíacos e neurológicos. Nesse momento inicial das investigações, Chagas considerou como sinal clínico mais característico da doença a hipertrofia da tireóide (bócio), expressa em aumento de volume do pescoço. Para ele, nas localidades onde havia a tripanossomíase, o bócio endêmico não era o mesmo que ocorria na Europa (que muitos já atribuíam à carência de iodo), mas o resultado da ação do T. cruzi na tireóide. Por isso a designação "tireoidite parasitária", proposta pelo médico Miguel Pereira (1871-1918).

Desde os primeiros estudos, Chagas afirmou que a nova enfermidade, que atingia os moradores de casas infestadas por barbeiros a partir das primeiras idades, produzia danos permanentes em seu desenvolvimento físico e mental; tratava-se, portanto, de uma endemia rural que prejudicava seriamente a modernização do país e deveria ser firmemente combatida pelos poderes públicos. Num momento em que o Brasil comemorava o progresso em sua capital litorânea recém-reformada, a ciência de Manguinhos revelava um 'outro país', marcado pela pobreza e pelo abandono: o Brasil do interior.

A nova moléstia tropical, assumindo contornos particulares como endemia dos sertões, passou a ser vista como 'doença do Brasil', em vários sentidos além do geográfico: símbolo de um 'país doente' e da ciência que indicaria os meios para sua 'redenção'.

Em meados da década de 1910, pesquisadores na Argentina questionaram as hipóteses de Chagas sobre as formas crônicas, afirmando que o bócio endêmico não tinha nenhuma relação com a tripanossomíase. Chagas reviu, então, alguns aspectos de sua concepção inicial. Mesmo mantendo a convicção sobre a etiologia parasitária do bócio endêmico, passou a tratá-lo como questão sujeita a discussão; ao mesmo tempo, reforçou a importância dos elementos cardíacos.

Depois de sua morte, suas hipóteses sobre os problemas endócrinos e neurológicos atribuídos à infecção pelo T. cruzi foram abandonadas, mas a forma cardíaca crônica foi amplamente confirmada. Distúrbios do trato digestivo, assinalados por Chagas sem maior aprofundamento, seriam também comprovados posteriormente.

Atualmente, considera-se que a doença de Chagas, em sua fase crônica, abrange a forma indeterminada (em que não se manifestam sintomas), a forma cardíaca e a forma digestiva. 

the collaboration of other researchers, Carlos Chagas explored a wide gamut of its features: the biological characteristics of the vector and parasite, Trypanosoma cruzi reservoirs, the disease's clinical presentation and evolution, diagnostic methods, and possible treatment options.

His papers on the disease were presented at Brazil's leading medical associations. In 1911, at the International Exposition on Hygiene and Demography in Dresden, Germany, the new illness drew intense interest. In 1912, Chagas received the Schaudinn prize in protozoology from the Hamburg Institute for Maritime and Tropical Diseases. The following year he was nominated for the Nobel Prize in medicine. It was then that the federal government pledged funds to build hospitals in Lassance and at Manguinhos where the disease would be investigated.

According to Chagas's earliest studies, the main symptoms of the first phase of infection by T. cruzi were fever; enlarged liver, spleen, and lymph nodes; and facial swelling, the latter a sign of a compromised thyroid. Chagas divided the acute phase into two forms: cases entailing serious brain disorders (generally involving children under the age of one, who almost never survived) and more common cases, devoid of such manifestations, which soon evolved to the chronic phase.

The chronic phase was characterized by endocrinological, cardiac, and neurological disturbances. When he first started his investigations, Chagas believed the most notable clinical characteristic of the disease was hypertrophy of the thyroid (goiter), manifested in increased neck size. For him, where trypanosomiasis was found in Brazil, the accompanying endemic goiter was not the same as in Europe (which many were already attributing to iodine deficiency) but was instead the result of T. cruzi's effect on the thyroid. Ergo the name parasitic thyroiditis, proposed by physician Miguel Pereira (1871-1918).

Right from the outset of his studies, Chagas held that the new illness, which struck people living in barbeiro-infested housing at very early ages, caused permanent damage to physical and mental development. He felt this rural endemic disease was a serious roadblock to the modernization of Brazil and that the public authorities should therefore combat it with a firm hand. At a time when the country was commemorating progress in its newly reformed seaside capital, science at Manguinhos was revealing "another country", marked by poverty and abandonment: rural Brazil.

The new tropical illness assumed specific features as a disease endemic to the country's hinterlands. Thus it came to be seen as "the disease of Brazil," and not just in the geographic sense: it was the symbol of a "diseased country" and of the science that would point the way to "redemption."

In the mid-1910s, researchers in Argentina began questioning Chagas's hypotheses about the chronic forms of the disease, arguing that endemic goiter had nothing to do with trypanosomiasis. Chagas then revised some elements of his initial conception. Although he still held that endemic goiter was of parasitic etiology, he began addressing it as a matter open to discussion, while reinforcing the importance of cardiac elements.

Chagas's hypotheses about the endocrinological and neurological disorders he had attributed to infection by $T$. cruzi were discarded after his death, whereas the chronic cardiac form was amply confirmed. Disorders of the digestive tract - which Chagas had pointed out but had not studied in detail - were later shown to be part of the disease as well.

The chronic phase of Chagas disease is now seen as encompassing the indeterminate form (asymptomatic), the cardiac form, and the digestive form. 


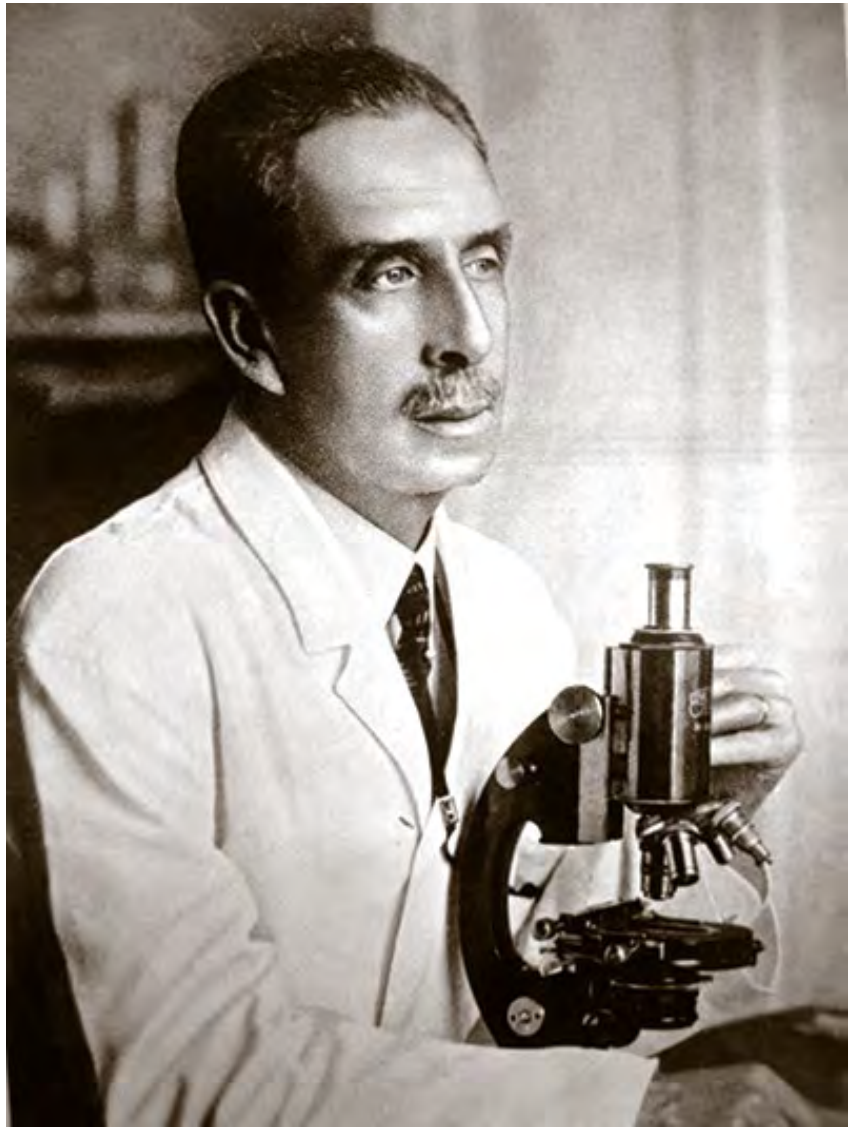

Imagem de abertura - Cafua em Lassance

Acervo Casa de Oswaldo Cruz

Opening image - Thatched wood and mud hut in Lassance

Carlos Chagas em seu laboratório no Instituto de Manguinhos

Acervo Casa de Oswaldo Cruz

Carlos Chagas in his laboratory at the Manguinhos Institute

Trabalho publicado por Chagas no primeiro volume das Memórias do Instituto Oswaldo Cruz, em agosto de 1909

Acervo Casa de Oswaldo Cruz

Paper published by Chagas in the first volume of Memórias do Instituto Oswaldo Cruz, in August 1909

\section{NOVA TRIPANOZOMIAZE HUMANA}

Estudos sobre a morfolojia e o ciclo evolutivo do Schizotrypanum cruzi n. gen., n. sp, ajente etiolojico de nova entidade morbida do homem

\section{UEBER EINE NEUE TRYPANOSOMIASIS DES MENSCHEN}

Studien über Morphologie und Entwicklungszyklus des Schizotrypanum cruzi n. gen., n. sp., Erreger einer neuen Krankheit des Menschen

VON

DR. CARLOS CHAGAS

Reimpresso das "MEMORIAS DO INSTITUTO OSWALDO CRUZ" Vol. I - Fac. II - Agosto 1909

Sonderabdruck aus den "MEMORIAS DO INSTITUTO OSWALDO CRUZ" Band I - Heft II - August 1909 

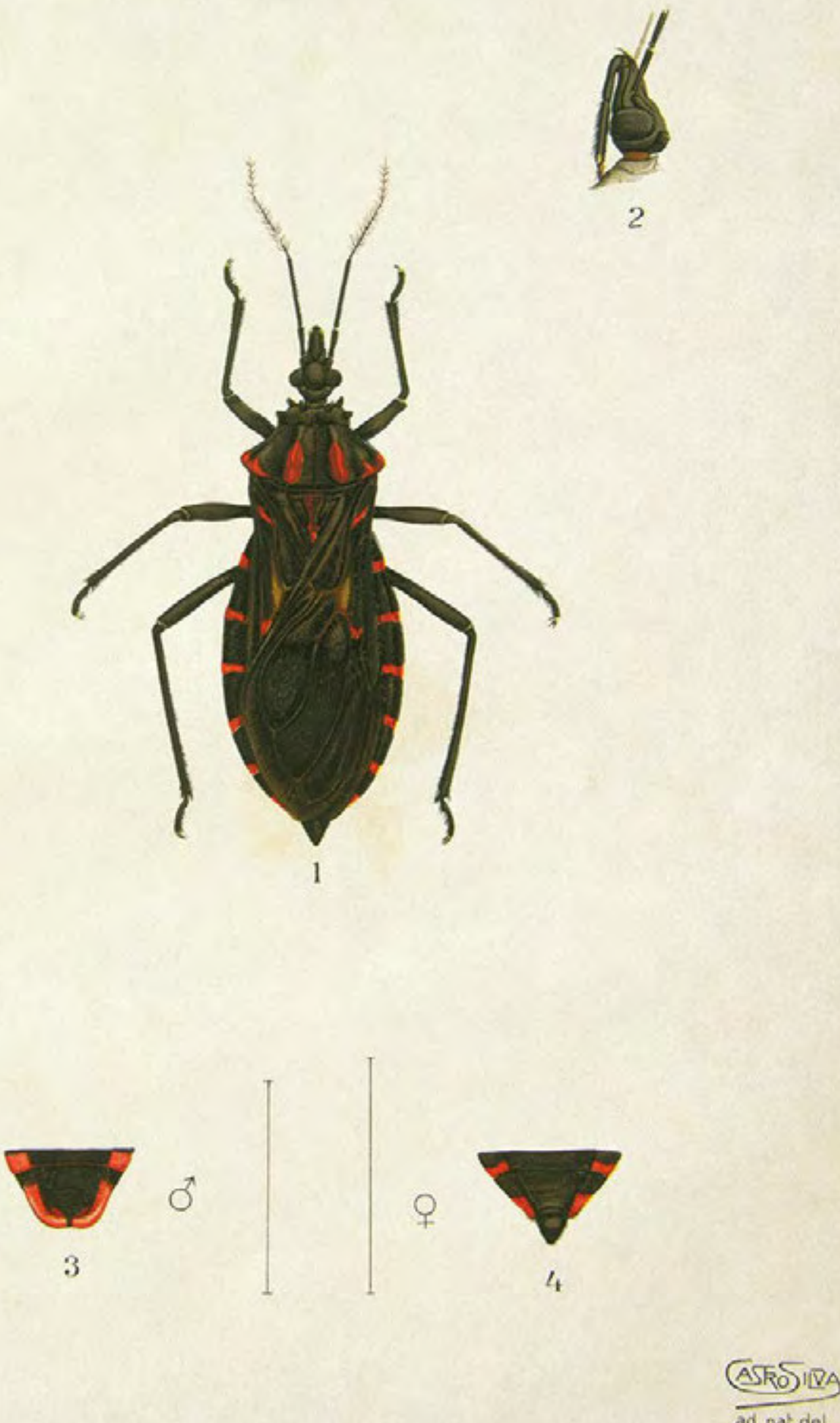

Conorhinus megistus, espécie de barbeiro encontrada em Lassance Prancha de Castro Silva publicada em artigo de Chagas nas

Memórias do Instituto Oswaldo Cruz, em agosto de 1909

Acervo Casa de Oswaldo Cruz

Conorhinus megistus, species of barbeiro found in Lassance

Engraved plate by Castro Silva, published in an article by Chagas in

Memórias do Instituto Oswaldo Cruz, in August 1909 
MEMORIAS DO INSTITUTO OSWALDO CRUZ Tомо I - 1909
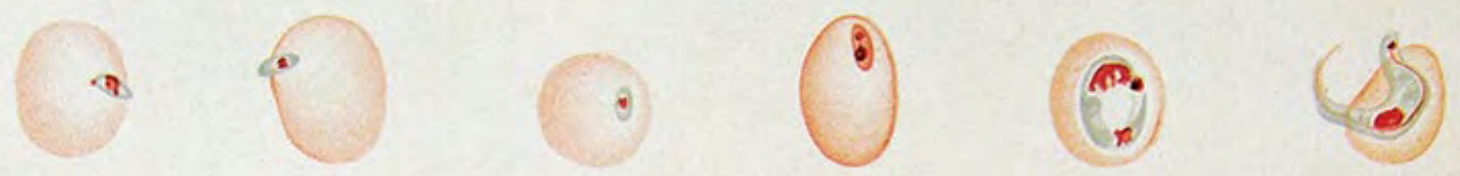

2

3

4

5

6

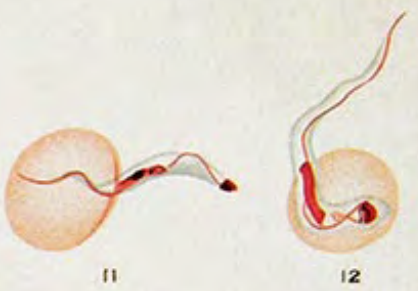

10

2
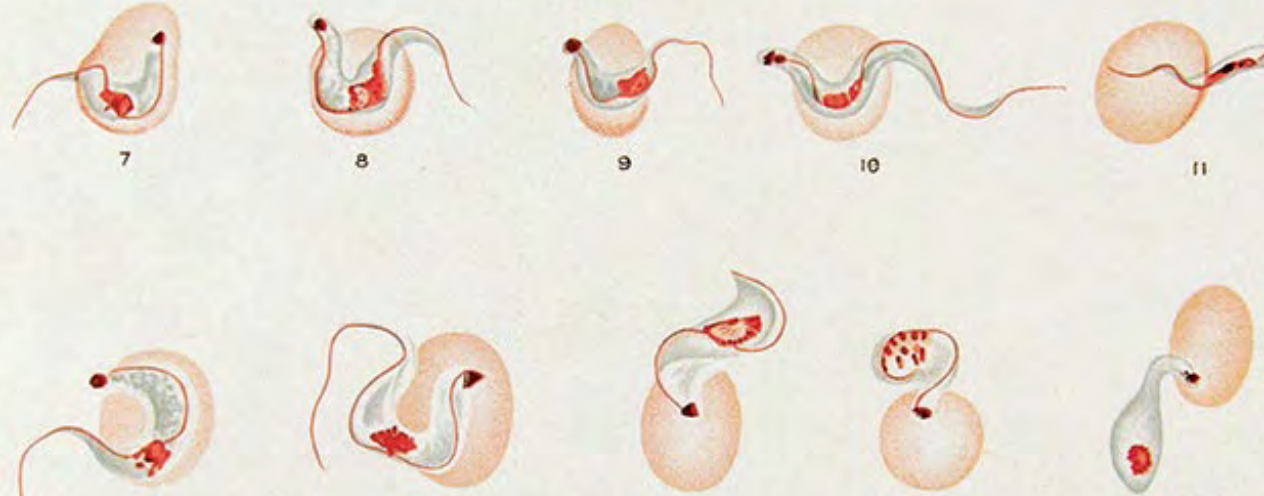

17

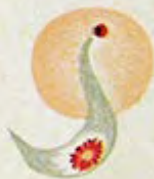

14

16

18

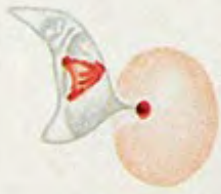

19

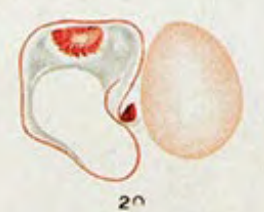

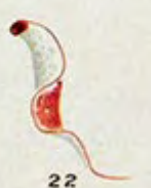
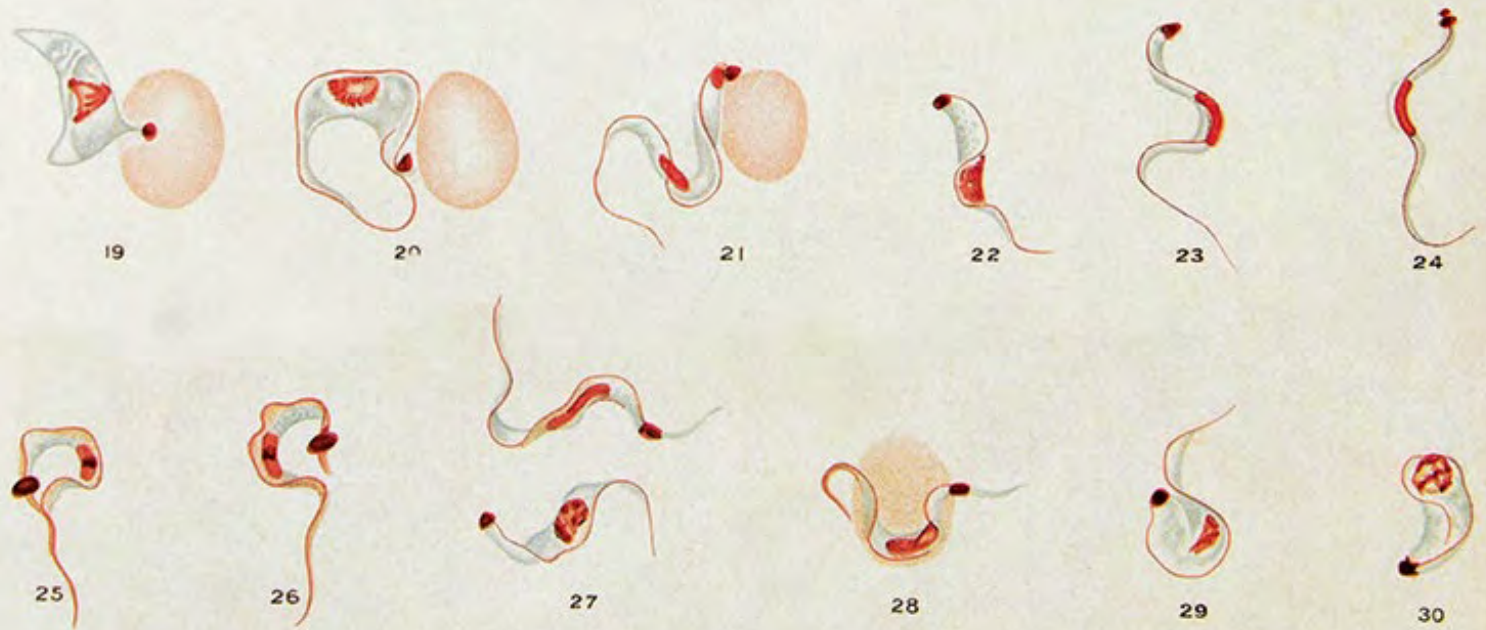

30

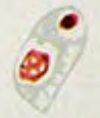

$(8$

31

32
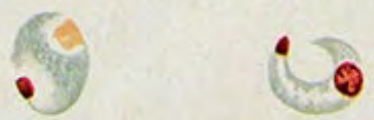

34
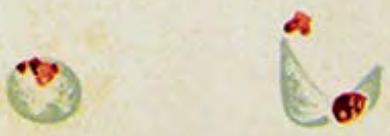

36

(ASTOSID

Estágios evolutivos do T. cruzi

Pranchas de Castro Silva publicadas em artigo de Chagas nas

Memórias do Instituto Oswaldo Cruz, em agosto de 1909

Acervo Casa de Oswaldo Cruz

Life cycle of Trypanosoma cruzi

Engraved plates by Castro Silva, published in an article by Chagas

in Memórias do Instituto Oswaldo Cruz, in August 1909 
MEMORIAS dO INSTITUTO OSWALdo CRUz Томо I - 1909

(3) $i$

3

Ei:?

25

$\because ;$

$a^{3} x$

$\therefore$

40

41

43

44

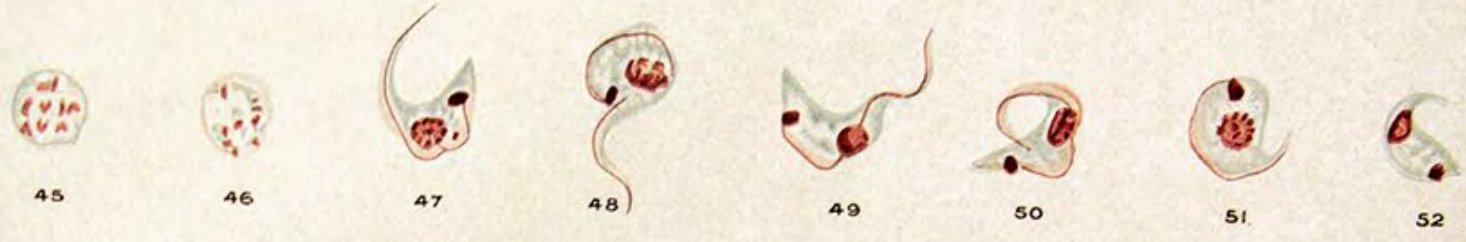

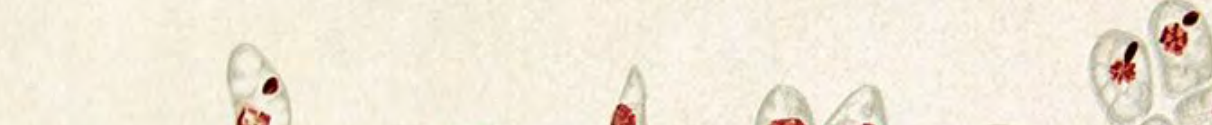

- II

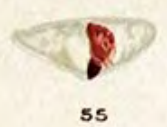

$\because 2$

1.

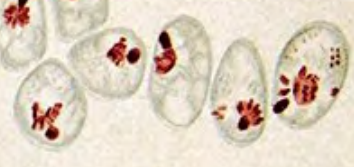

53

54

$56 \quad 57$

59
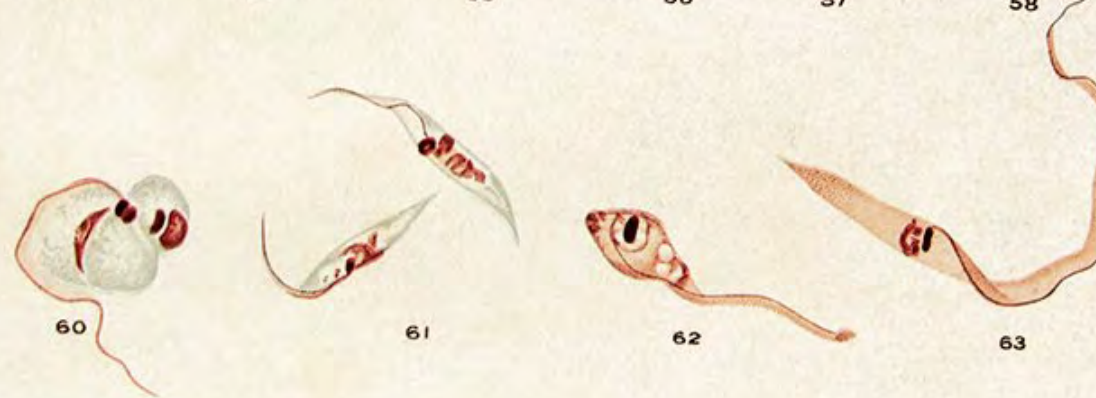

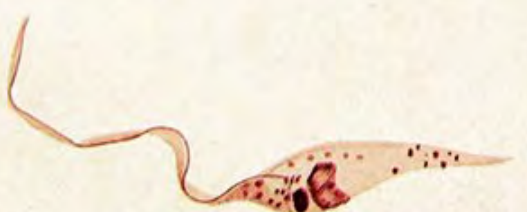

65

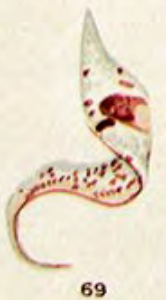

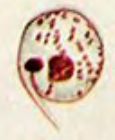

70
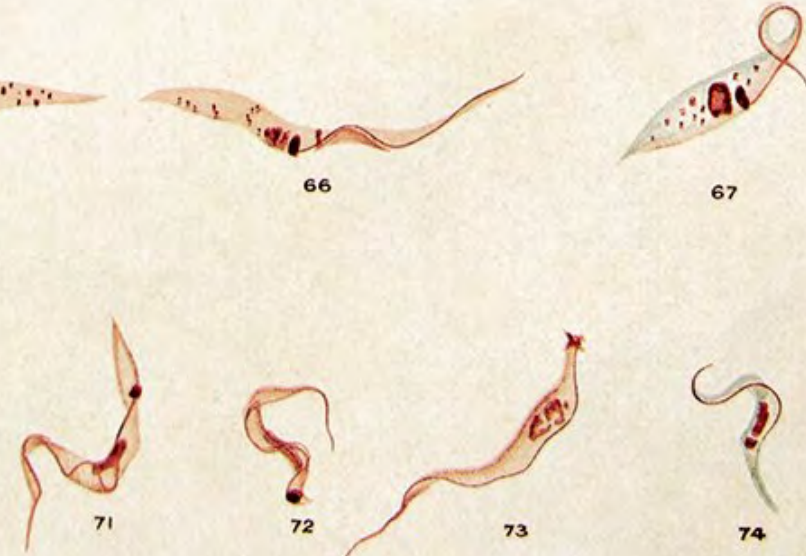

67

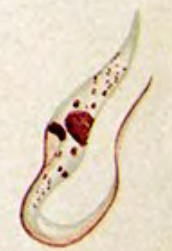

68
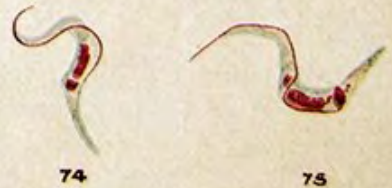

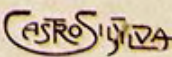


MEMORIAS DO INSTITUTO OSWALDO CRUZ Tомо I - 1909

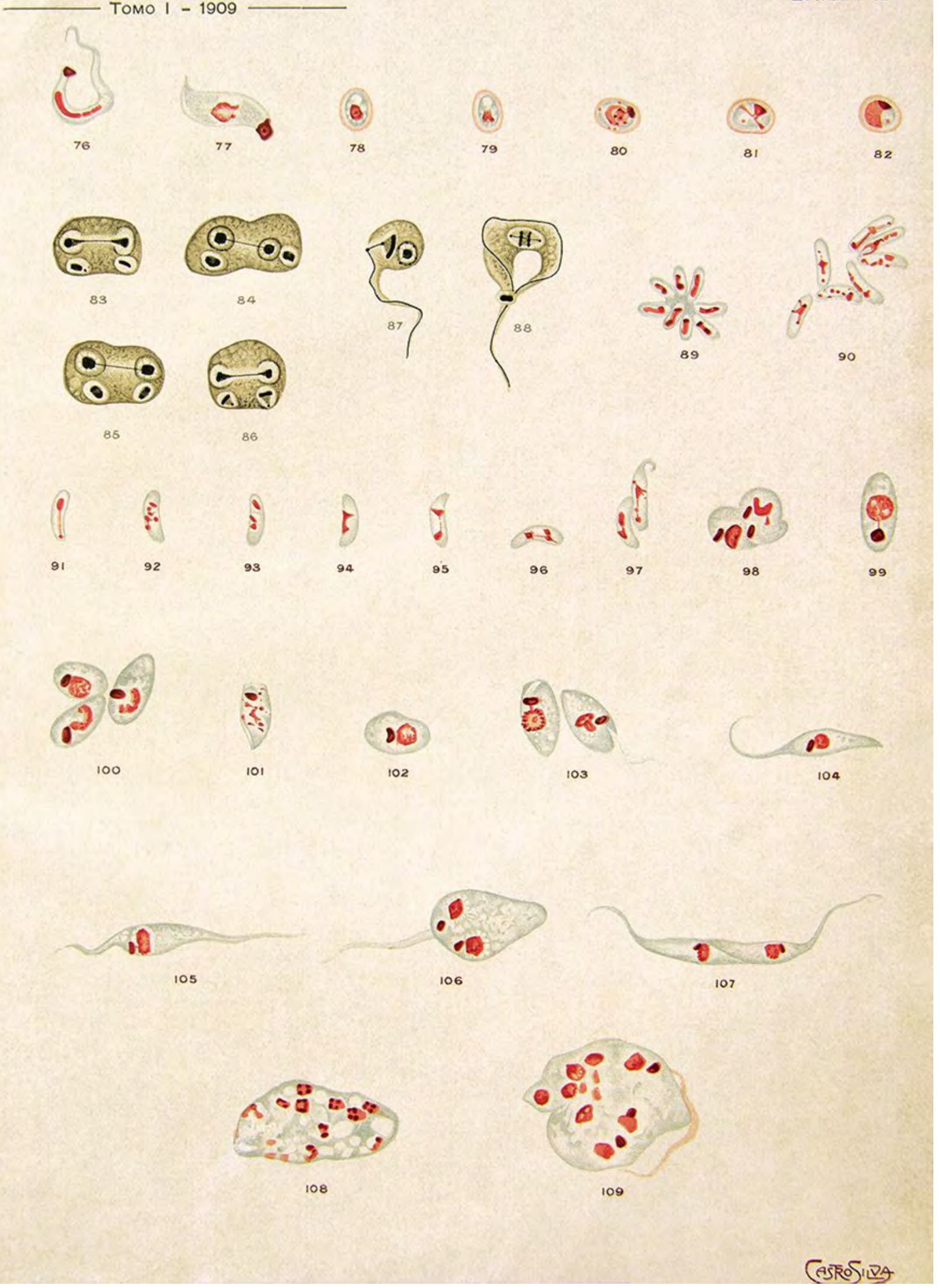




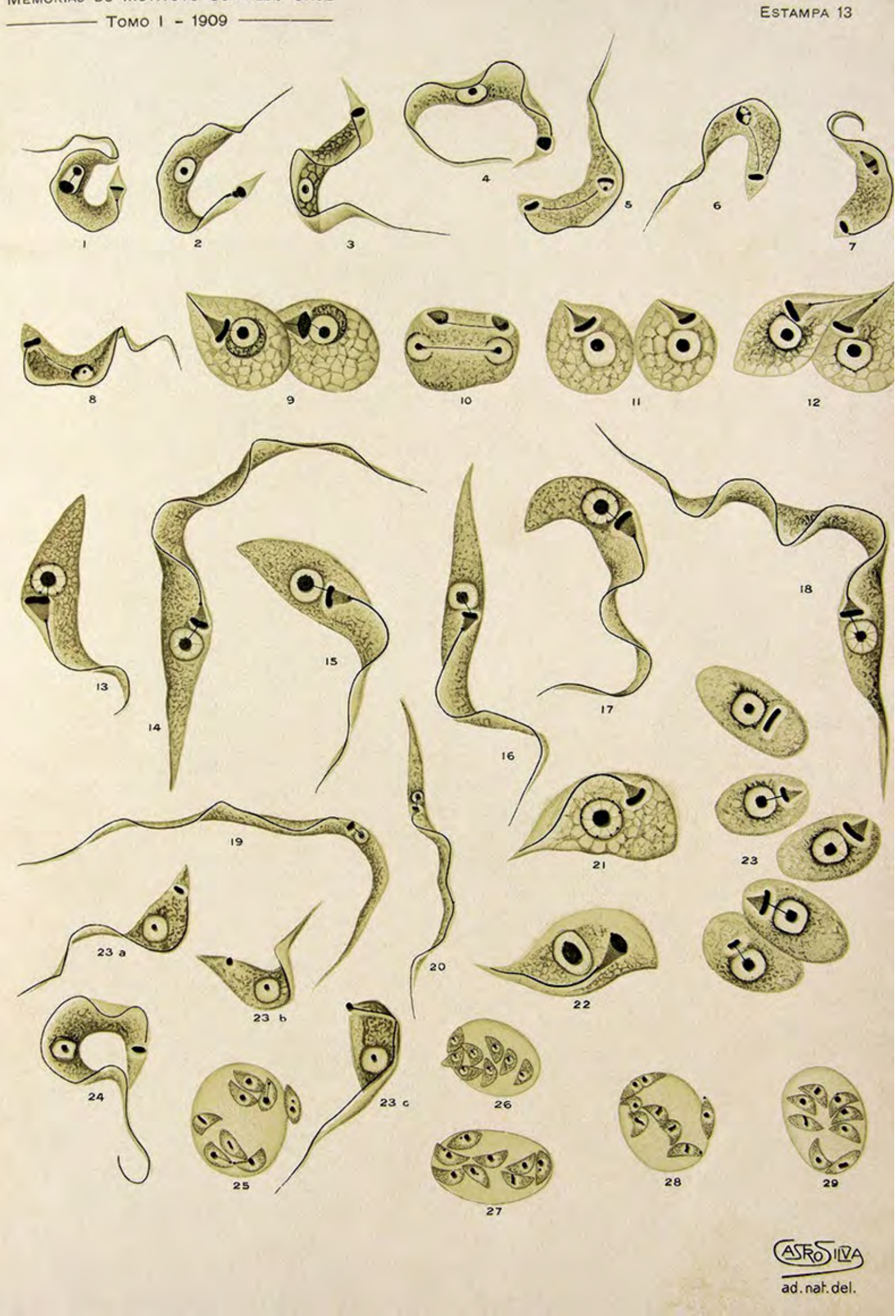




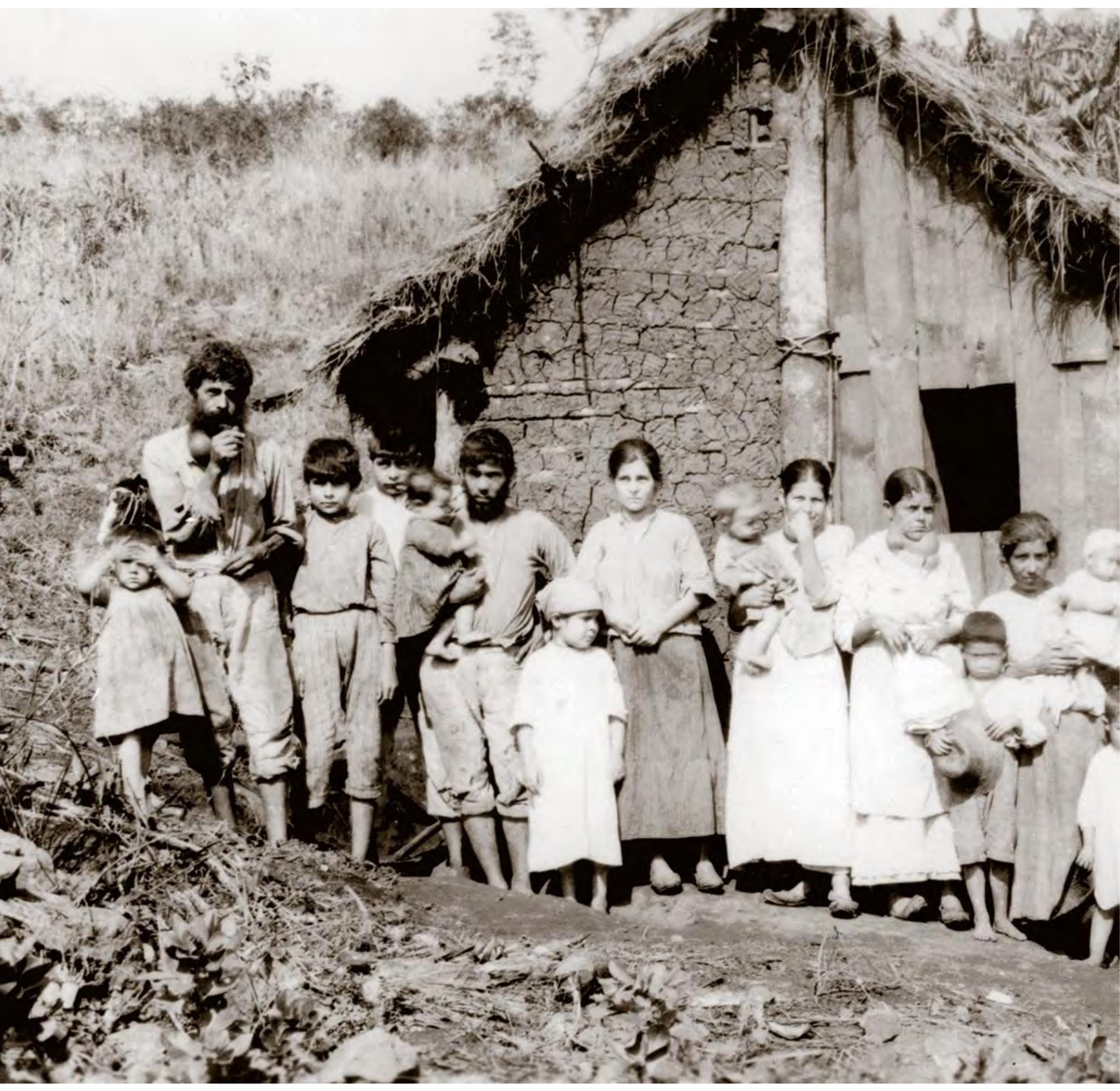

Grupo em Lassance, em habitação típica das

populações rurais, com paredes de barro e

cobertura de capim ou palha, conhecida como

cafua

Acervo Casa de Oswaldo Cruz

Group in Lassance in a typical rural home, with

mud walls and grass-or straw-thatched roof

known as a cafua 


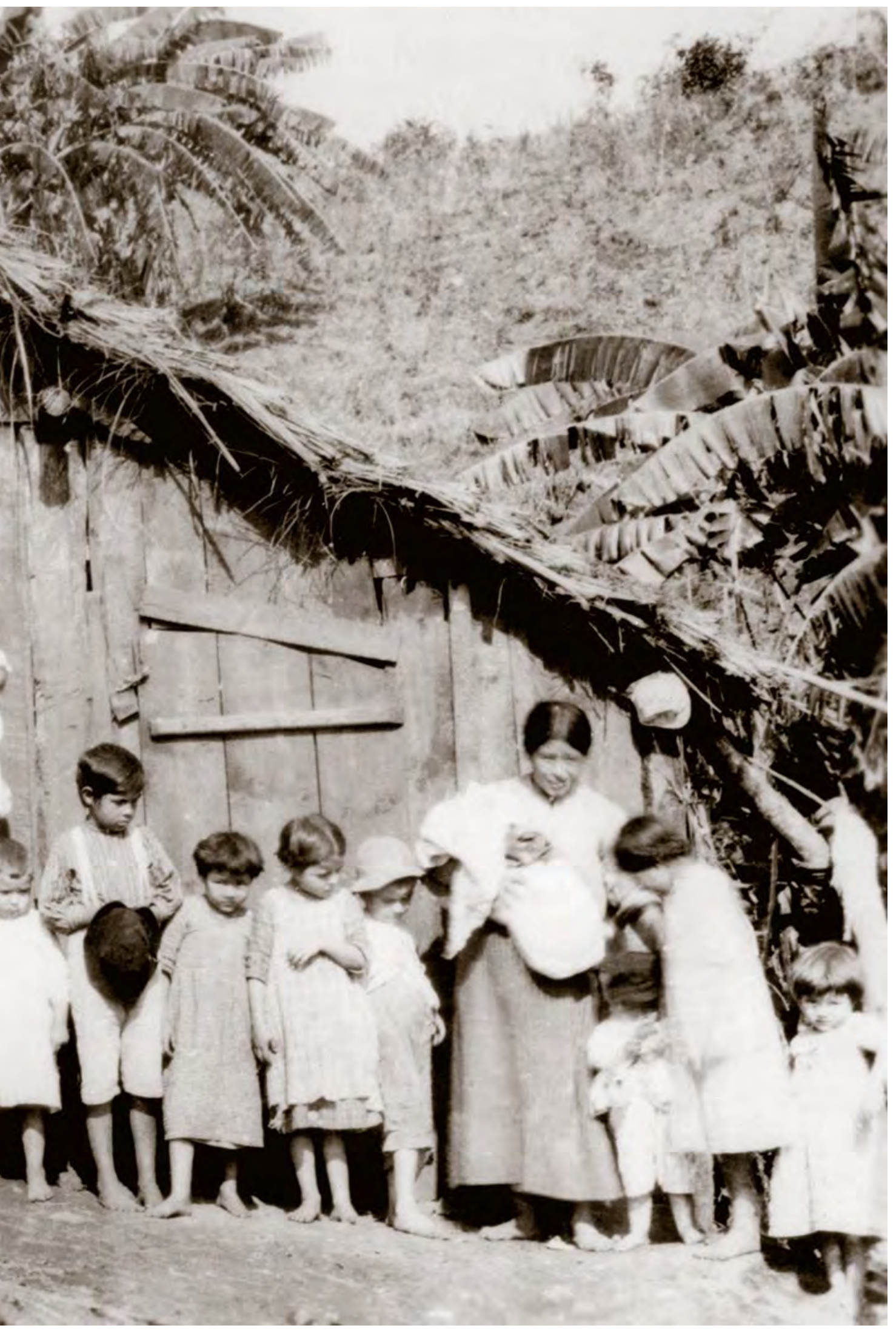

... lá pelo interior do país, nas zonas da moléstia, a população pobre habita choupanas nas mais precárias condições, tendo as paredes cheias de numerosas fendas, que constituem ninhos colossais de Conorhinus.

Carlos Chagas

(...) there in the interior of the country, in the regions of the disease, the poor population dwells under the most precarious conditions, in huts whose walls are filled with many cracks, forming enormous nests of Conorhinus.

Carlos Chagas 

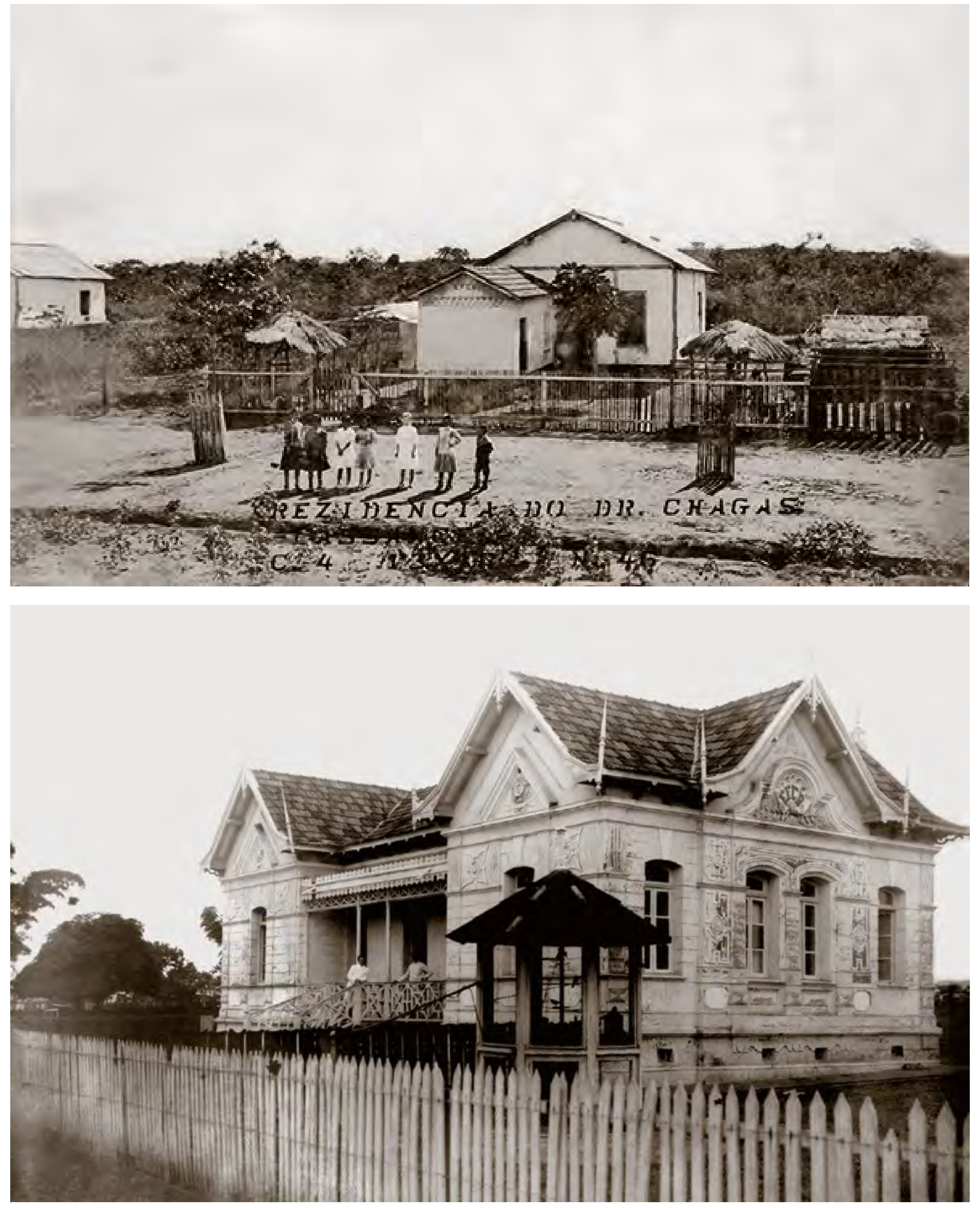

Residência de Chagas em Lassance Acervo Casa de Oswaldo Cruz

Chagas's residence in Lassance

Hospital regional de Lassance Acervo Casa de Oswaldo Cruz

Lassance regional hospital 


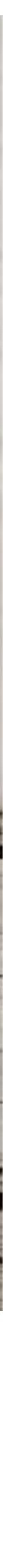



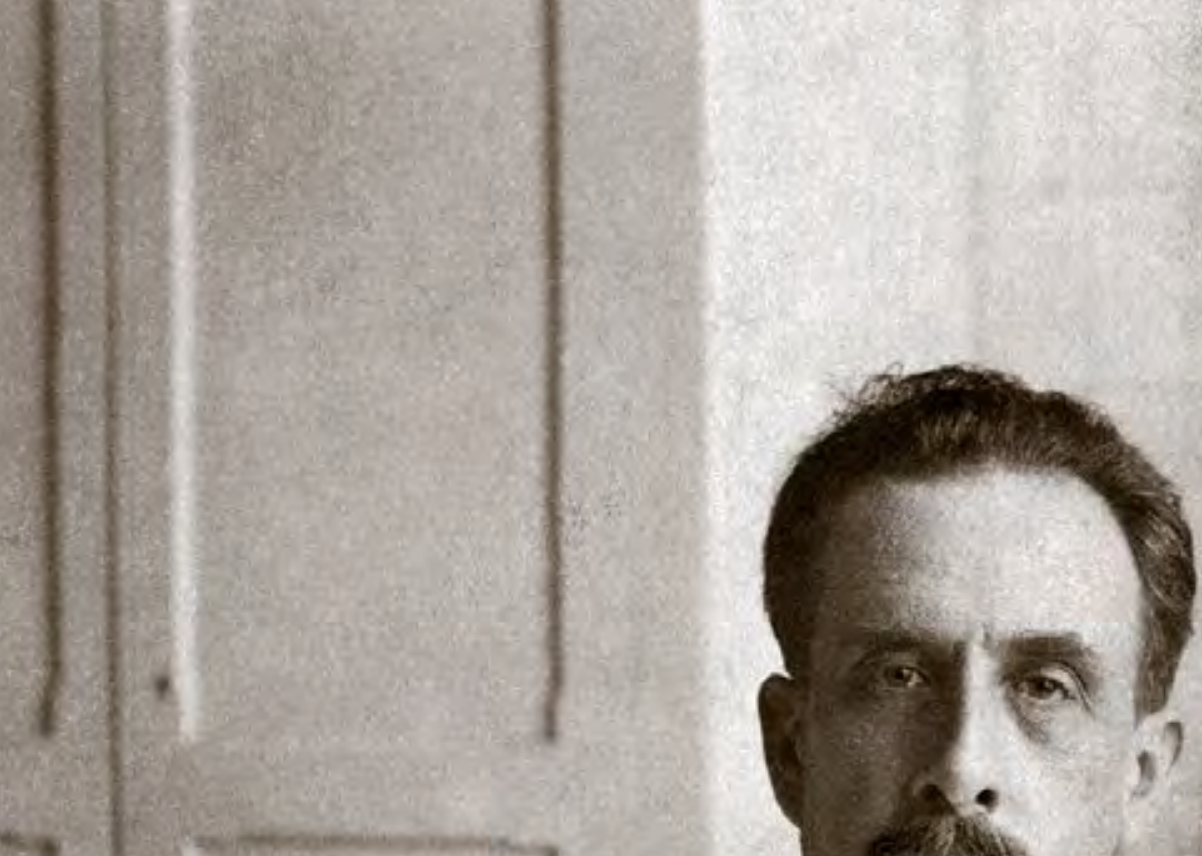
Chagas em seu laboratório no Instituto de Manguinhos Acervo Casa de Oswaldo Cruz

Chagas in his Manguinhos Institute laboratory

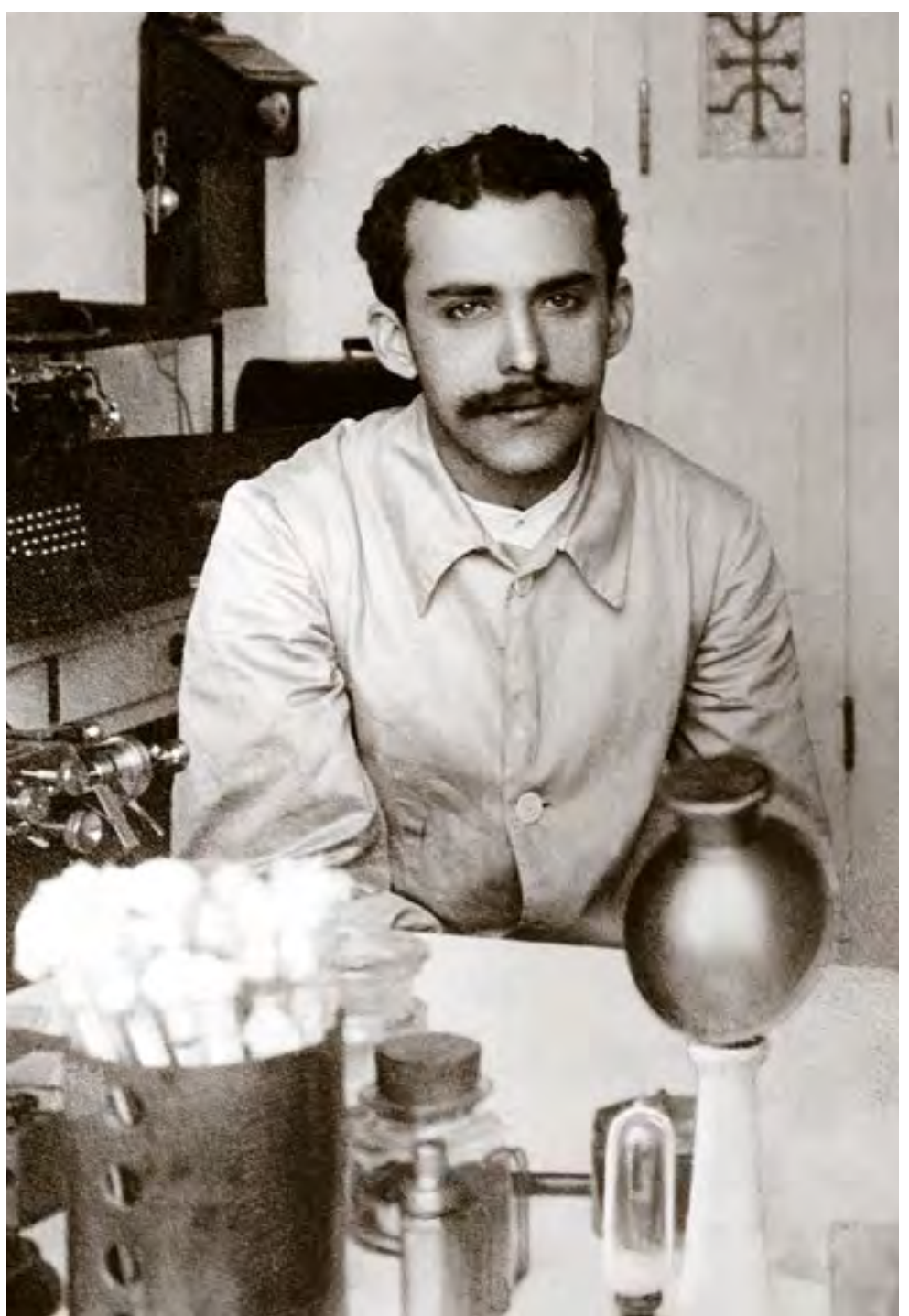

Os estudos de anatomia patológica de Gaspar Vianna (1885-1914) foram decisivos para a compreensão da ação patogênica do $T$. cruz

Acervo Casa de Oswaldo Cruz

Gaspar Vianna's (1885-1914) studies in pathological anatomy made a decisive contribution to understanding the pathogenic action of Trypanosoma cruzi

Arthur Neiva (1880-1943) estudou as diferentes espécies de barbeiros

Acervo Casa de Oswaldo Cruz

Arthur Neiva (1880-1943) studied the various species of barbeiros

Astrogildo Machado (1885-1945) desenvolveu, em 1913, em parceria com César Guerreiro (1885-1949), o primeiro método sorológico de diagnóstico para a doença de Chagas e realizou estudos em busca de um medicamento para a doença Acervo Casa de Oswaldo Cruz

In 1913, in collaboration with César Guerreiro (1885-1949), Astrogildo Machado (1885-1945) developed the first serological technique for diagnosing Chagas disease and did research to try to find a drug treatment
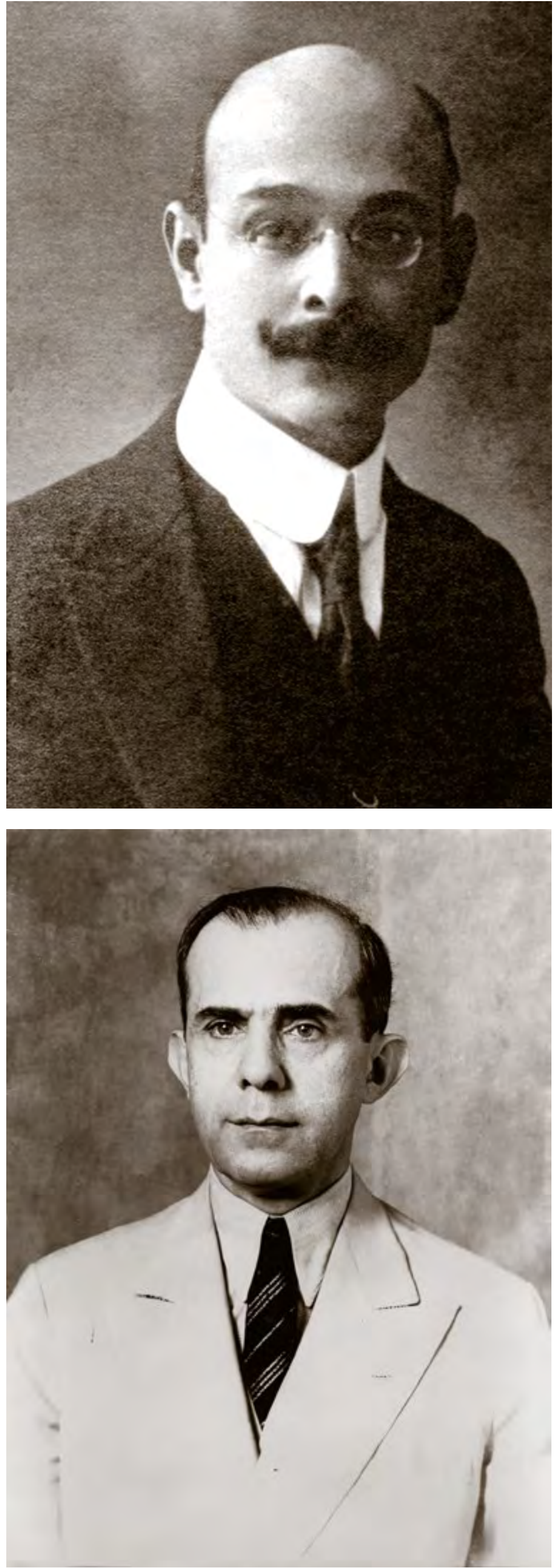

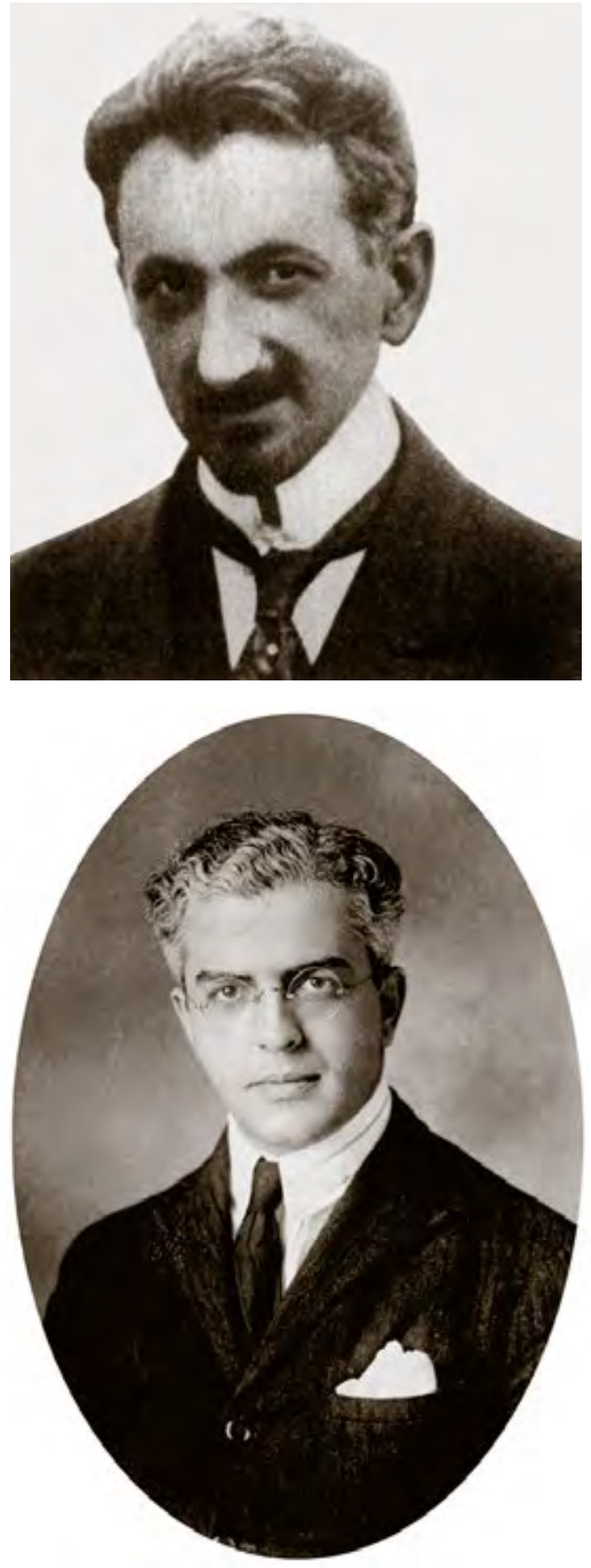

Ezequiel Dias (1880-1927) realizou pesquisas sobre os aspectos hematológicos da doença de Chagas e testou inseticidas contra os barbeiros

Acervo Casa de Oswaldo Cruz

Ezequiel Dias (1880-1927) conducted research on hematological aspects of Chagas disease and tested insecticides for use against barbeiros

Carlos Bastos de Magarinos Torres (1891-1984) empreendeu importantes estudos sobre a patologia da tripanossomíase americana

Acervo Casa de Oswaldo Cruz

Carlos Bastos de Magarinos Torres (1891-1984)

undertook important studies on the pathology of

American trypanosomiasis

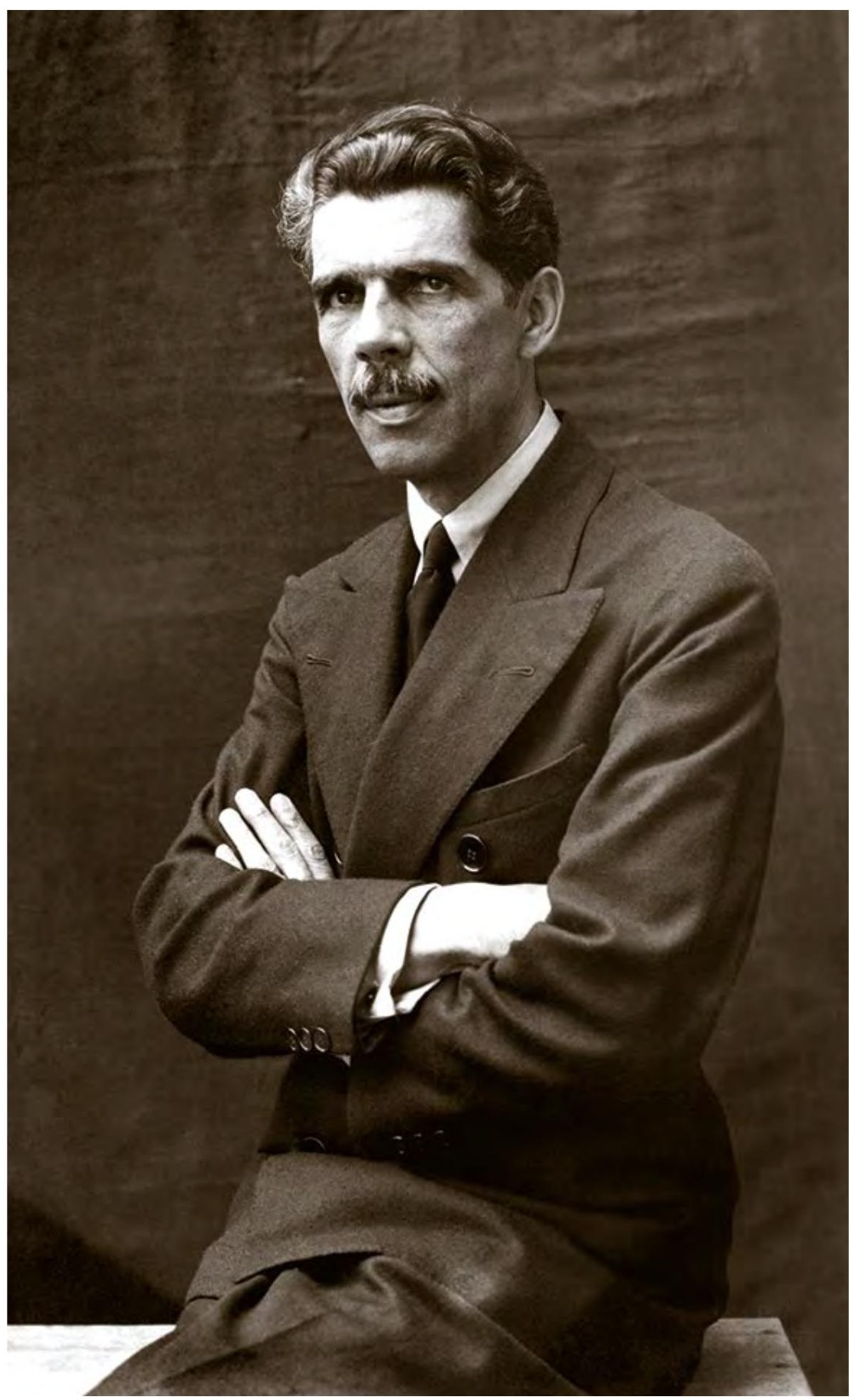

Eurico Villela (1883-1962), primeiro diretor do Hospital Oswaldo Cruz, foi importante colaborador no estudo da forma

cardíaca da tripanossomíase americana

Acervo Casa de Oswaldo Cruz

Eurico Villela (1883-1962), first director of the Oswaldo Cruz Hospital, was an important collaborator in research into the cardiac form of American trypanosomiasis

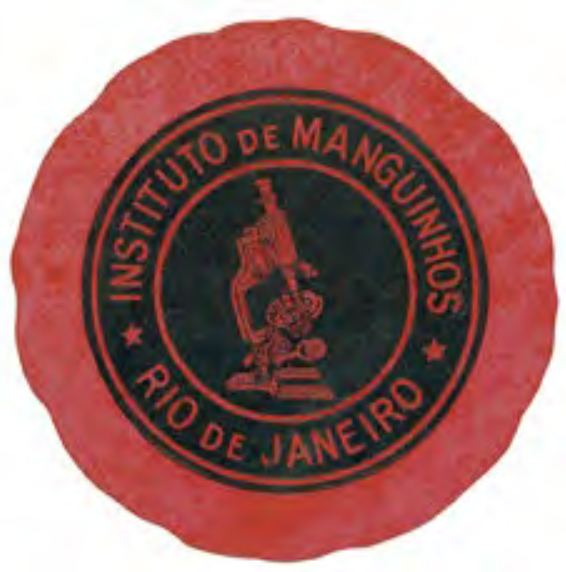



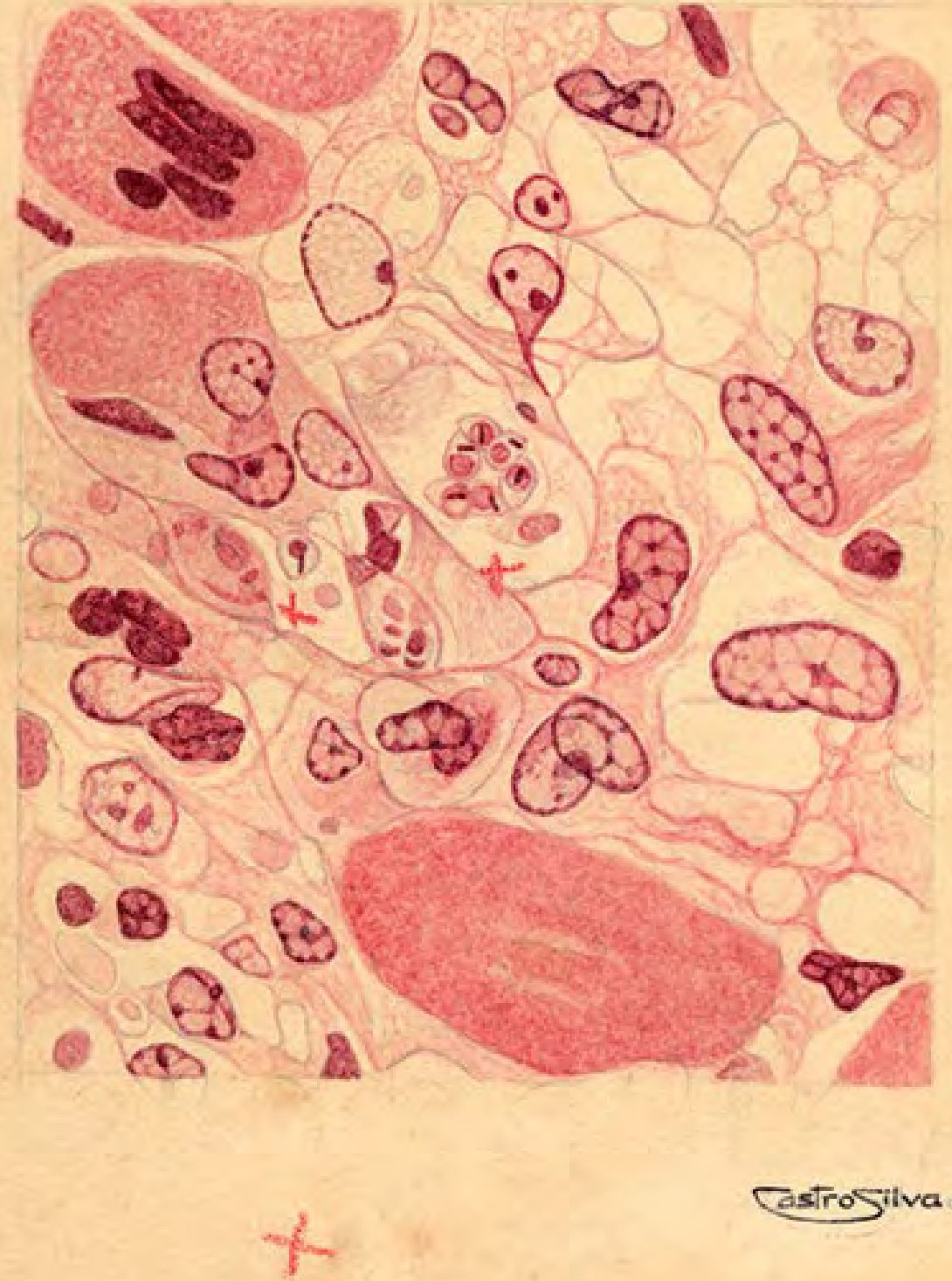

Castrositva del.

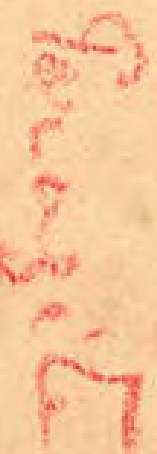

Ao patrimônio da escola de Oswaldo Cruz, muita vez o tenho afirmado, pertencem os trabalhos relativos à tripanossomíase americana; $e$ se glórias neles pudessem ser proclamadas, delas partilhariam todos os trabalhadores de Manguinhos.

Carlos Chagas

\section{Studies on American}

trypanosomiasis stand among the assets of the Oswaldo Cruz school, as I have often stated; and if any glory may be attributed to them, all workers at Manguinhos share in it.

Carlos Chagas 
MEMORIAS DO INSTITUTO OSWALDO CRUZ
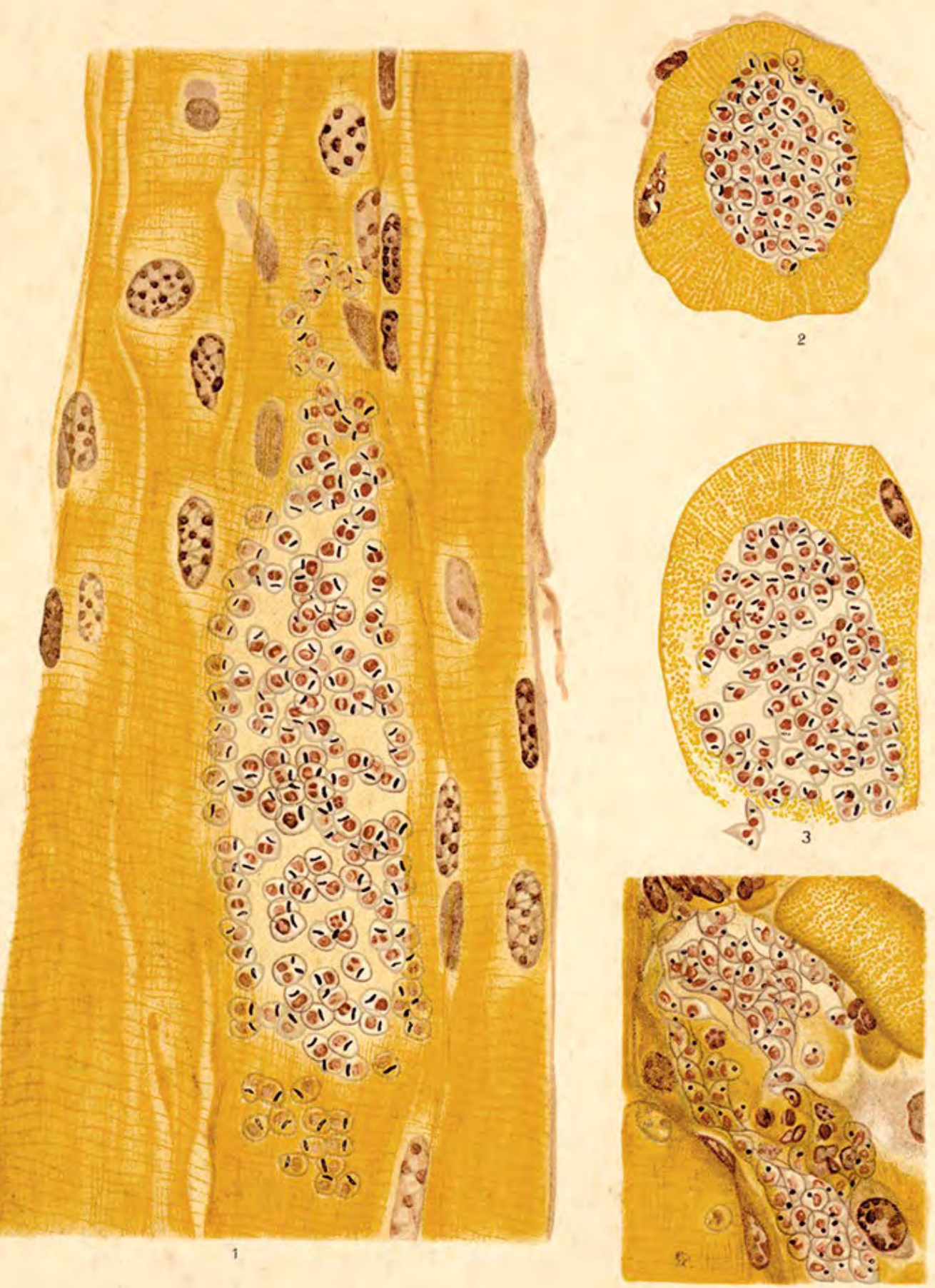

CastroSilva del.

Cortes histológicos indicando a presença do T. cruzi nos tecidos,

publicados em artigo de Gaspar Vianna nas Memórias do Instituto Oswaldo Cruz, em 1911

Prancha de Castro Silva

Acervo Casa de Oswaldo Cruz

Histological sections indicating the presence of T. cruzi in tissues, published in an article by Gaspar Vianna in Memórias do Instituto Oswaldo Cruz, in 1911

Engraved plate by Castro Silva

Folhas iniciais de manuscrito de Carlos Chagas sobre a nova tripanossomíase

Acervo Casa de Oswaldo Cruz

First pages of a manuscript by Carlos Chagas on the new trypanosomiasis 
5 - ESTUDOS SOBRE A DOENÇA DE CHAGAS | RESEARCHING CHAGAS DISEASE

reypousomian bazile: Mova merbitia Luma

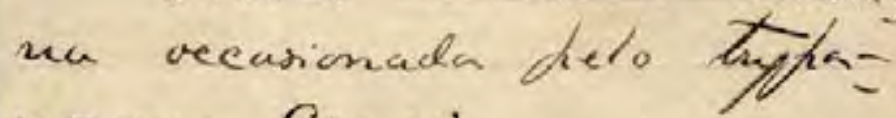
nozme Cruzi.

Trabalho realiade sab a diveciaio ob dr. Comald Cruz felo -

- Ir Cantor Chag chefe de cersico of in Z.tato Qsralds Cing. Snorymi:

Schizatrefounge. Shimes: lite paragitaria.

Defimicas.

4 thyfiangomiase braplaira $i$ unua nublt. \& in symbtomatosic ens. hera, ore de evrlacal agnah, o mais das vegs de evvluça Chonica, grassand entancicamena nas fmon contamenaly, onde recarima un eleven caefficiente da lethatihle

Ueu is elementh eundibs seacis

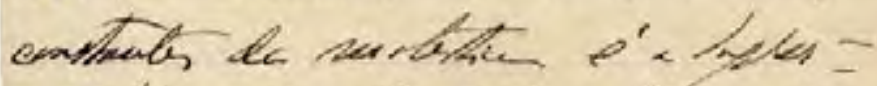
Fythic la flewdol tisrende, an formaci- frewert de xulueses decion.

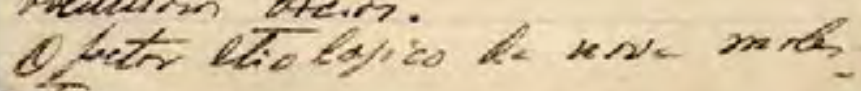

t' un hewo-thagellas, deceminas dy heroposma cruzici, Haus som tito sota picada de une quantle hematophago, o Préato ma negistal prumean= Fras vas Smicitios las. manes abigass mas peases on hacedes a atacaras o han wen á usite, a mota ds

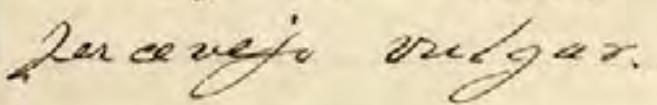

Systhematica do parazita. A haveng-, no cyclo biologico do pungit Q now mebtio, de nua divisán multigle egular no pulmer on vertebras e a curmeai de divisa. engitulinal hinasia no sangue ferifherico levaram was à creaceas a un novo geners, o genero schizothypa:

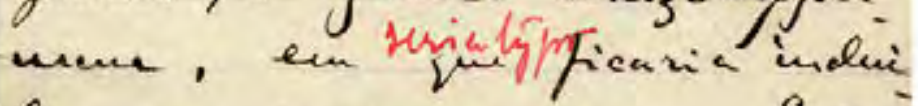
da a nova trecie. Estu: dos porterious, provin, ualigaos no Litituto de Slanguicwher (Traballon de A. Rachado ef. Vianua) vieram dermy tran a enistencia de una divisa. multipla no trypa

125 

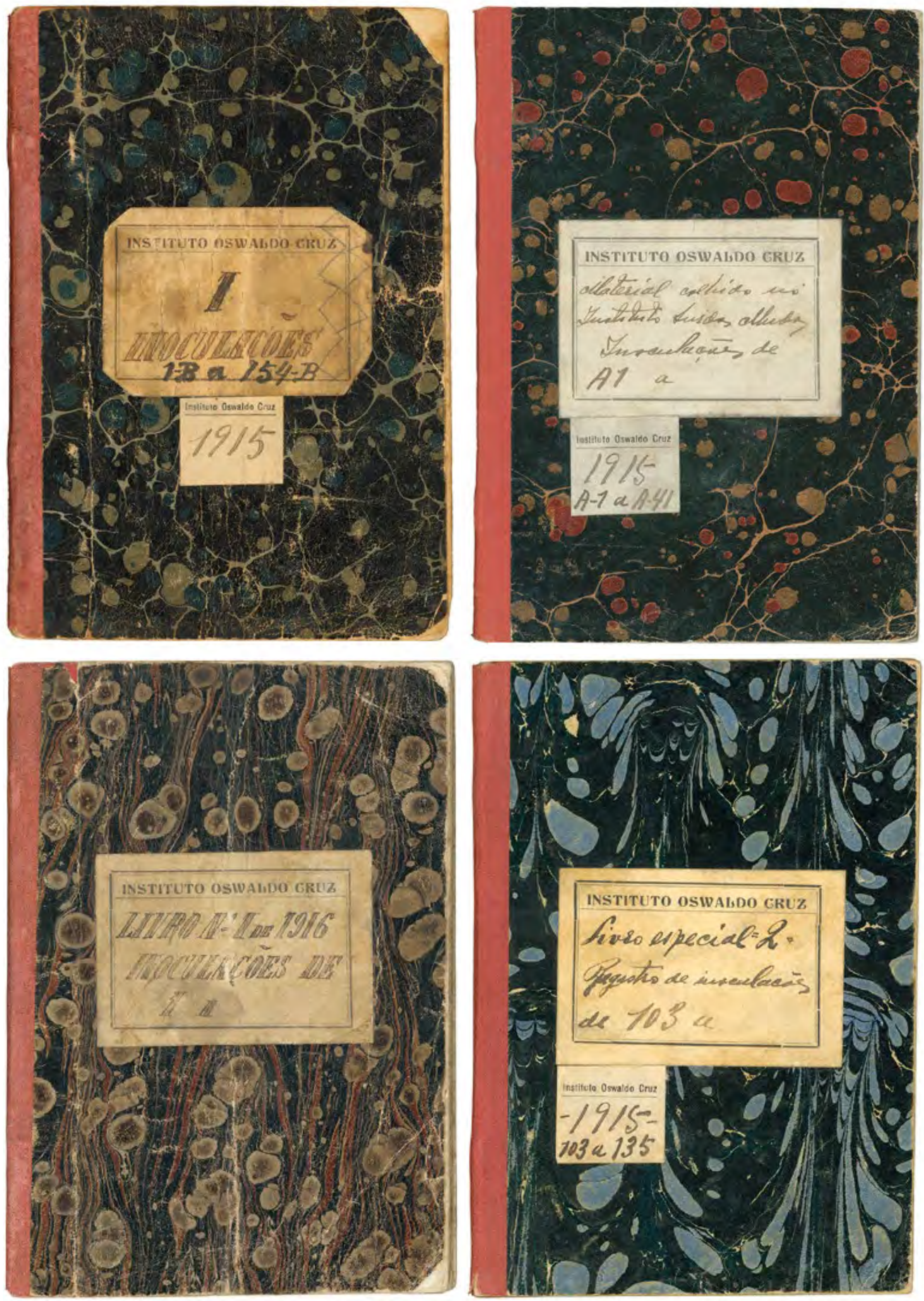
5 - ESTUDOS SOBRE A DOENÇA DE CHAGAS I RESEARCHING CHAGAS DISEASE

$$
\text { Din ted juch a } 1 s / s
$$

3sutis, un cat a un ondit invala:

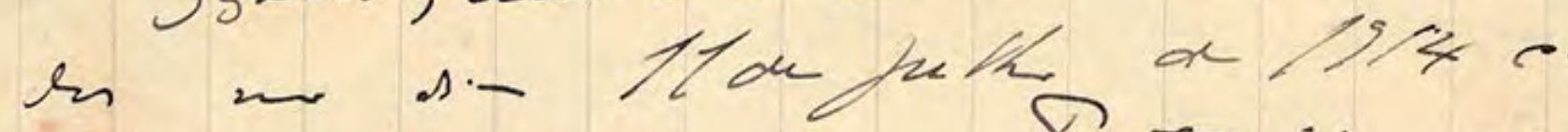
rangur $\alpha$ menin- Setzeki-, Sangy

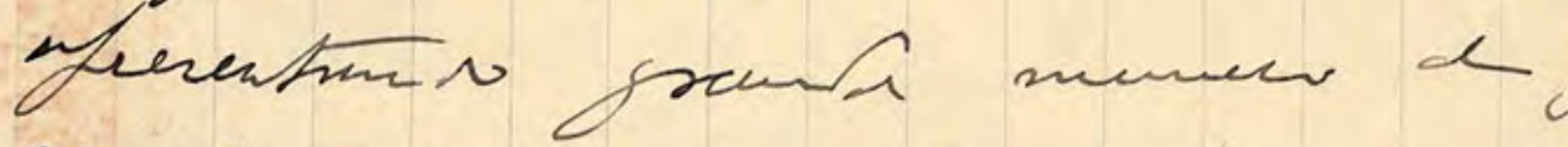
Qn ansuria afureut $\alpha$ format tinas Gaial 12 - as grotur - gavila IIC cuchorritho. 8.14 a jiek.

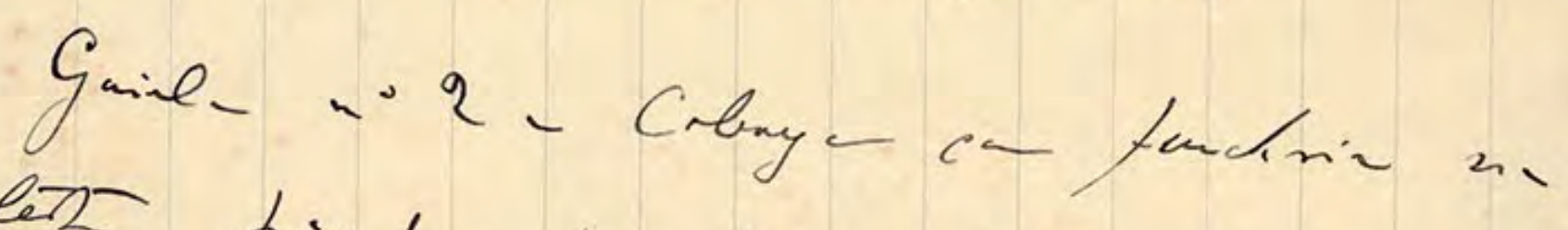

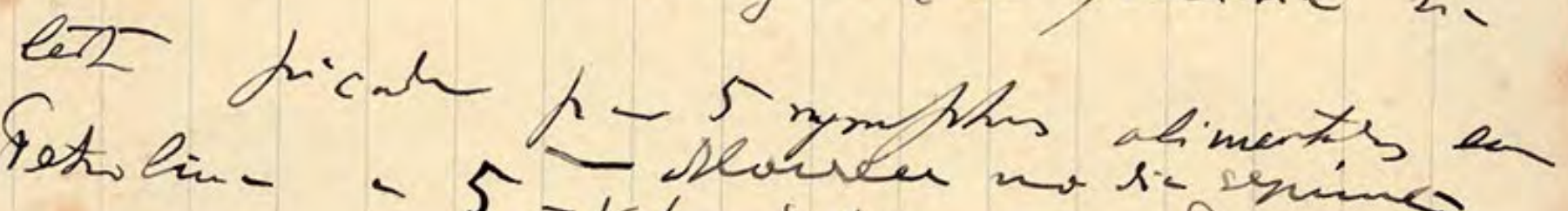

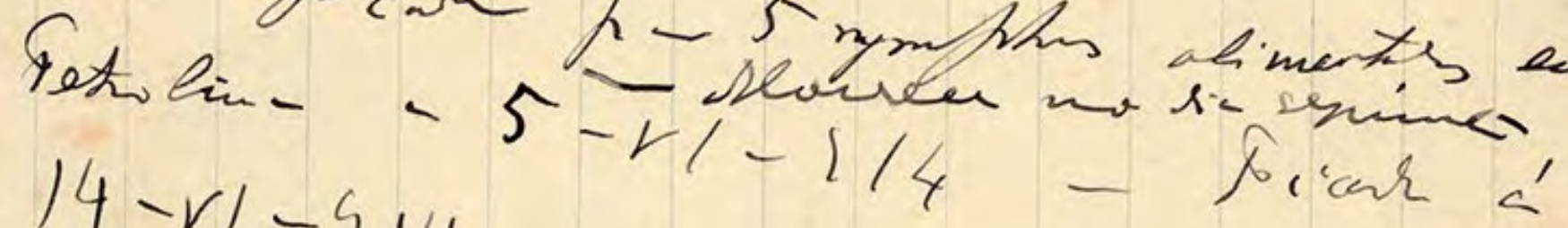
$14-11-914$.

Di- Is e gich,

Cobuy- inocular can ramme of we-

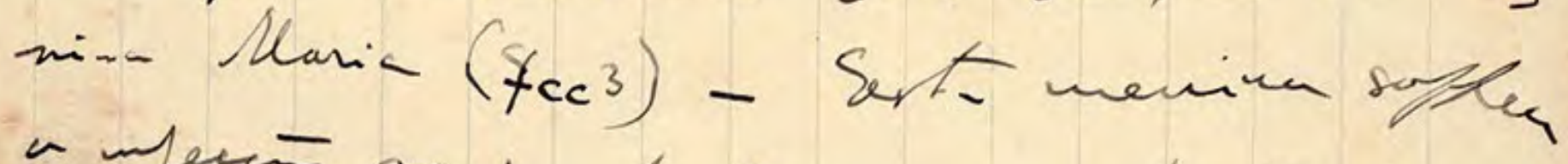

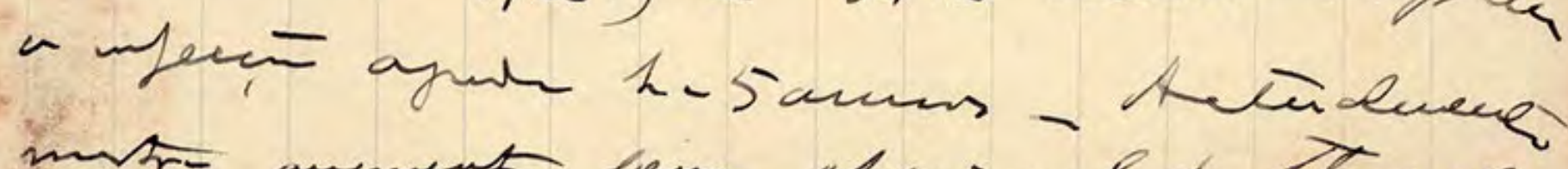

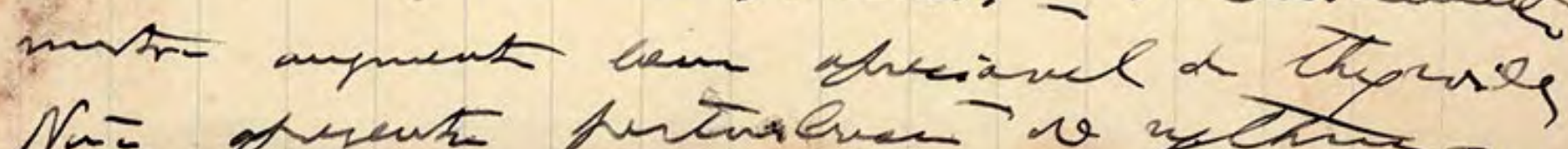

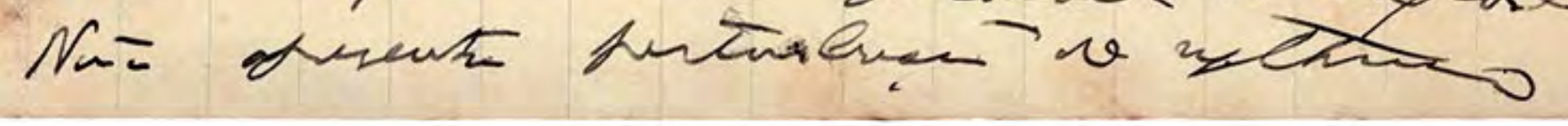

Anotações de Carlos Chagas sobre experiências de inoculação do
em julho de 1914 Acervo Casa de Oswaldo Cruz

Carlos Chagas's notes on experiments in which

Trypanosoma cruzi was inoculated in
experimental animals, conducted in July 1914

127 


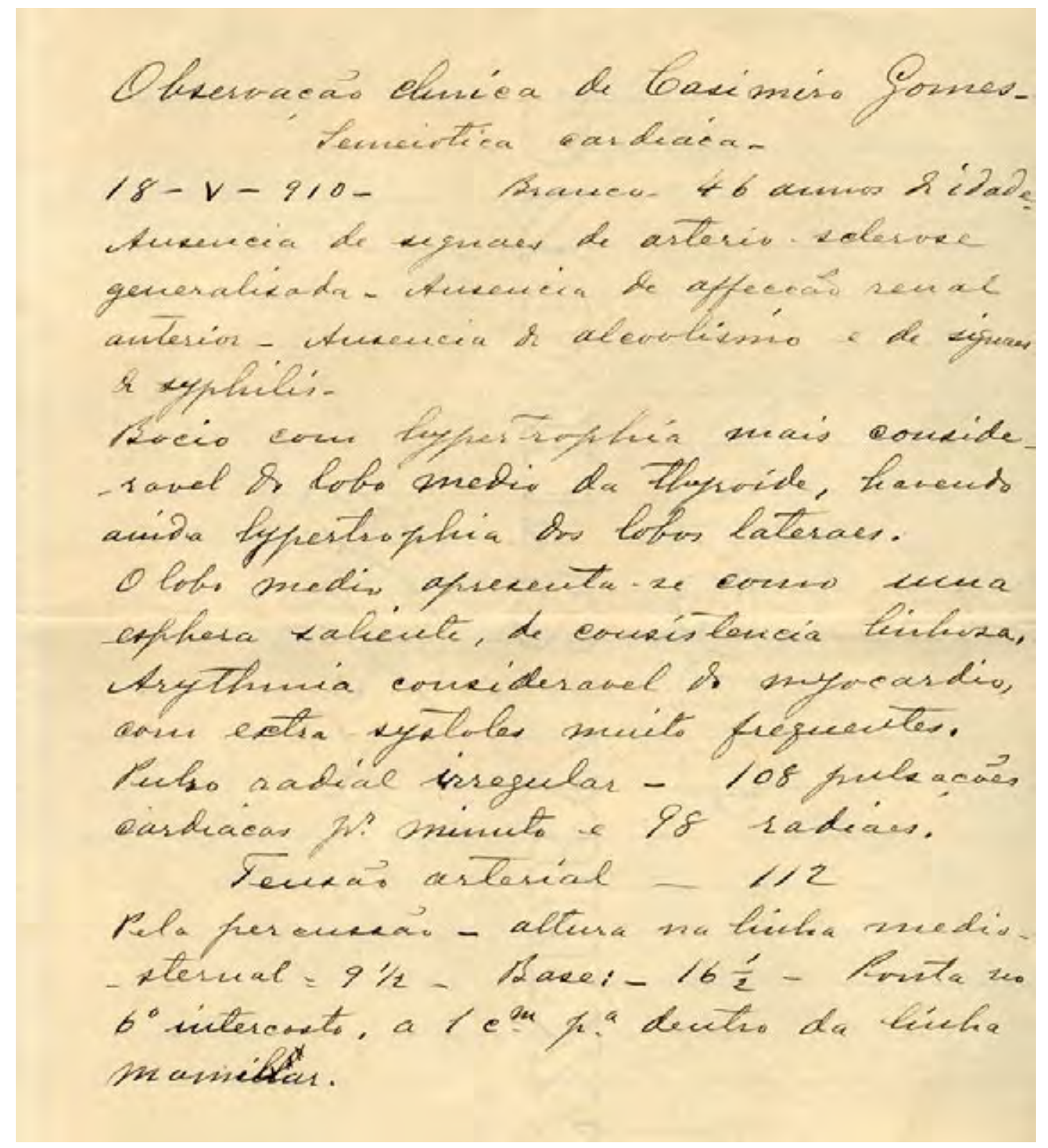

Observações sobre os sintomas cardíacos

de um paciente, em 18 de maio de 1910

Acervo Casa de Oswaldo Cruz

Observations on a patient's cardiac

symptoms, May 18, 1910

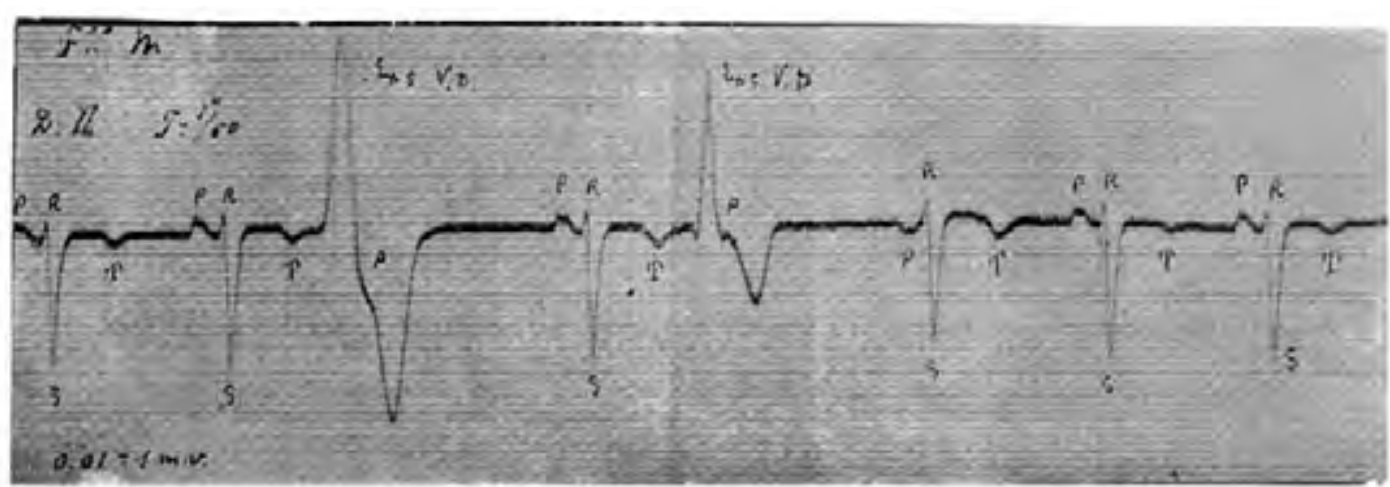

Traçado eletrocardiográfico de morador de Lassance com a forma cardíaca da doença. Chagas foi pioneiro no uso do eletrocardiógrafo no Brasil

Publicado em artigo de Carlos Chagas e Eurico Villela

nas Memórias do Instituto Oswaldo Cruz em 1922

Acervo Casa de Oswaldo Cruz

Electrocardiographic tracing of a resident of Lassance

presenting the cardiac form of the disease. Chagas

pioneered the use of electrocardiography in Brazil

Published in an article by Carlos Chagas and Eurico

Villela in Memórias do Instituto Oswaldo Cruz in 1922 

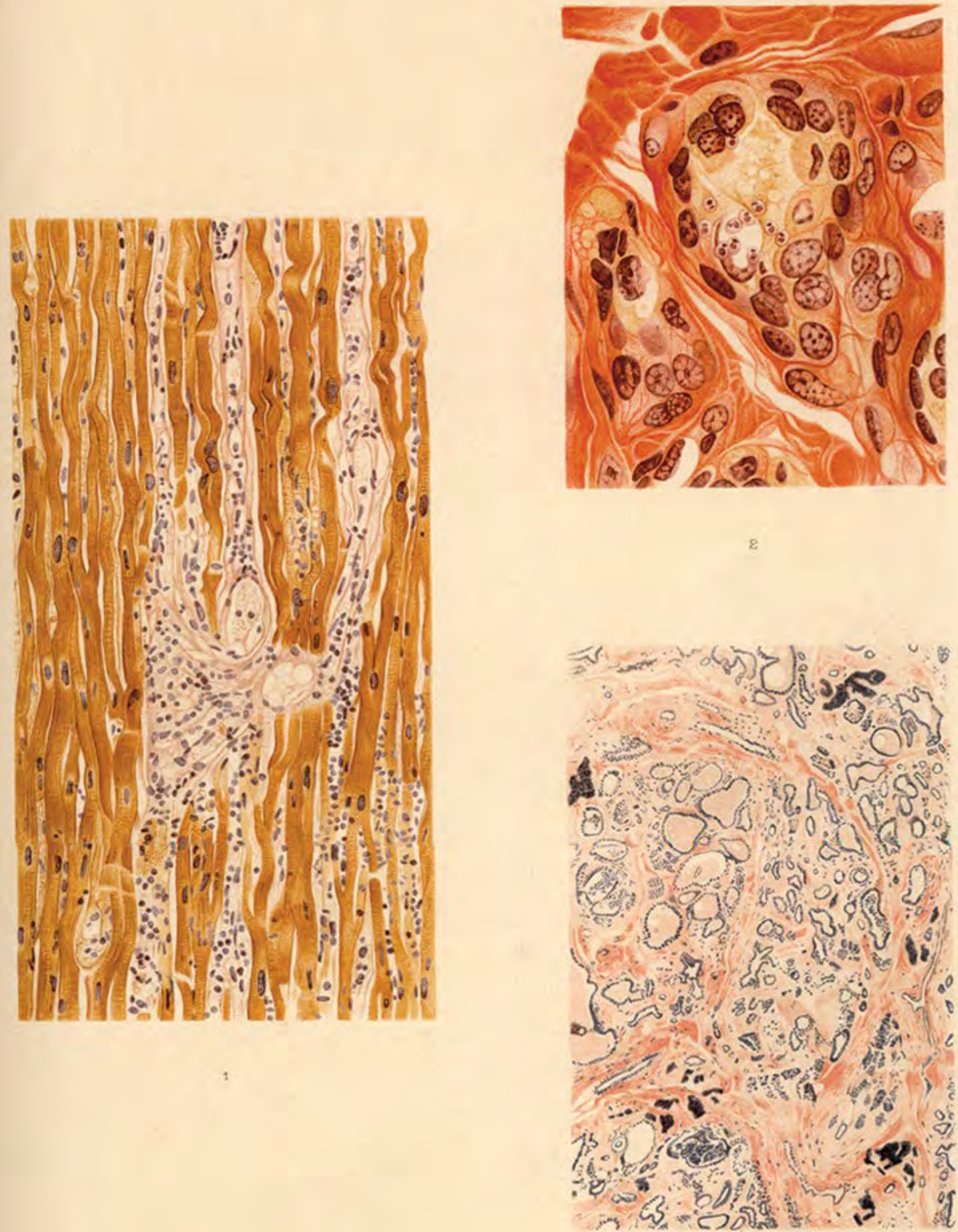

3

Castrosilva del.

Cortes histológicos publicados em artigo de Chagas nas Memórias do Instituto Oswaldo Cruz em 1916 


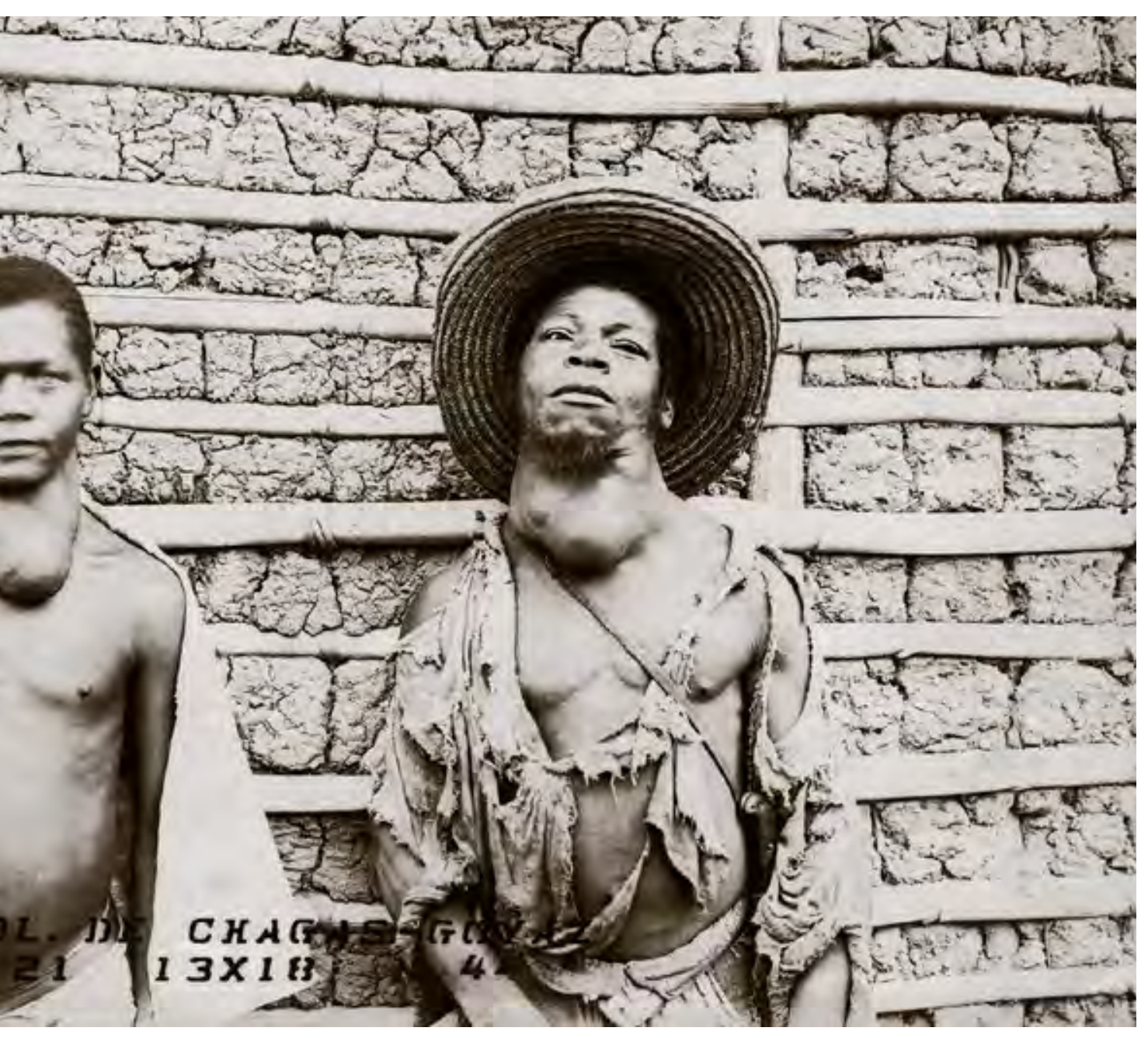

É habitual dizer-se, e nós mesmos já temos cometido esse pecado, que o povo sertanejo é indolente e sem iniciativa. A verdade, porém, é outra. A ausência de esforço e iniciativa dessa pobre gente é proveniente do abandono em que vive, e da incapacidade fisica e intelectual resultante de moléstias deprimentes e aniquiladoras, cabendo nessas regiões à moléstia de Chagas a primazia desse malefício.

Arthur Neiva e Belisário Penna

It is usually said - and we ourselves have committed this sin - that the sertanejos are lazy and lack initiative. Yet the truth is otherwise. These poor people's lack of drive and initiative derives from the state of abandonment in which they live, and from their physical and intellectual incapacity, which results from depressing, destructive sicknesses, with Chagas disease the worst such evil in these regions.

Arthur Neiva and Belisário Penna 



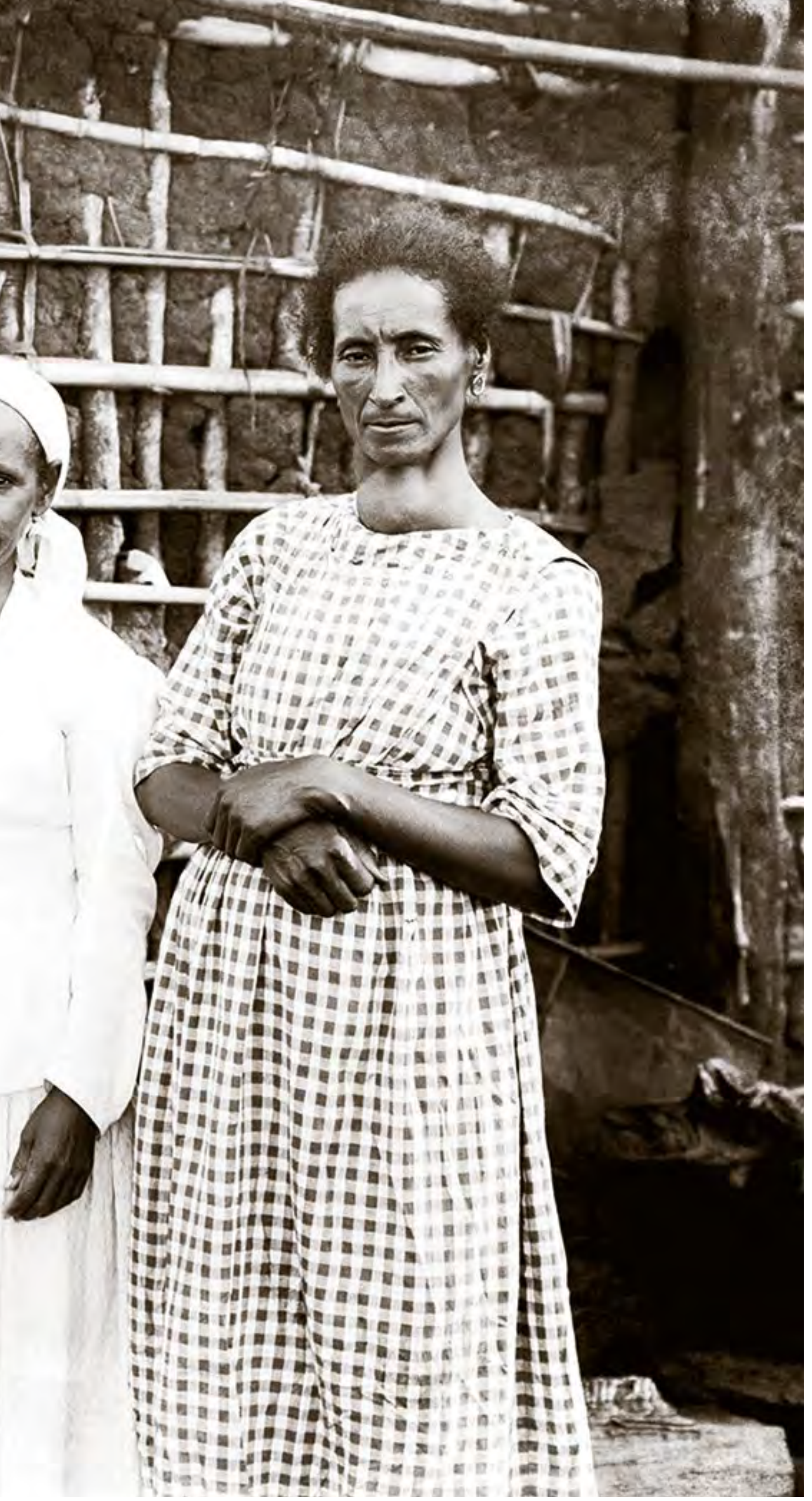

Vi tudo isso, vi, talvez, mais do que isto, mas nem tudo sei exprimir na forte impressão que me causaram os fatos observados. E, quando vendo ainda passar diante de minha retina mental a figura da miséria humana que a moléstia identificou corporizada e semimorta na imensidade de sua desdita, só consigo voltar a mim mesmo considerando o trabalho científico que visa à redenção daquele povo, e, num natural desvelo patriótico, descanso aos acenos da esperança de uma profilaxia inadiável, em trabalho fecundo e salvador.

Clementino Fraga

I saw all this - all this and perhaps more - but what I observed left such a deep impression that I do not know how to express it all. And when, moving across my mind's eye, I still see that figure of human misery made manifest and embodied in the disease, halfdead in the enormity of its misfortune, I am only able to return to my senses if I remember the scientific work that seeks to redeem these people and, with natural patriotic fervor, I place my trust in the hopeful signs of urgently needed prophylaxis through fruitful, salvational work.

Clementino Fraga 

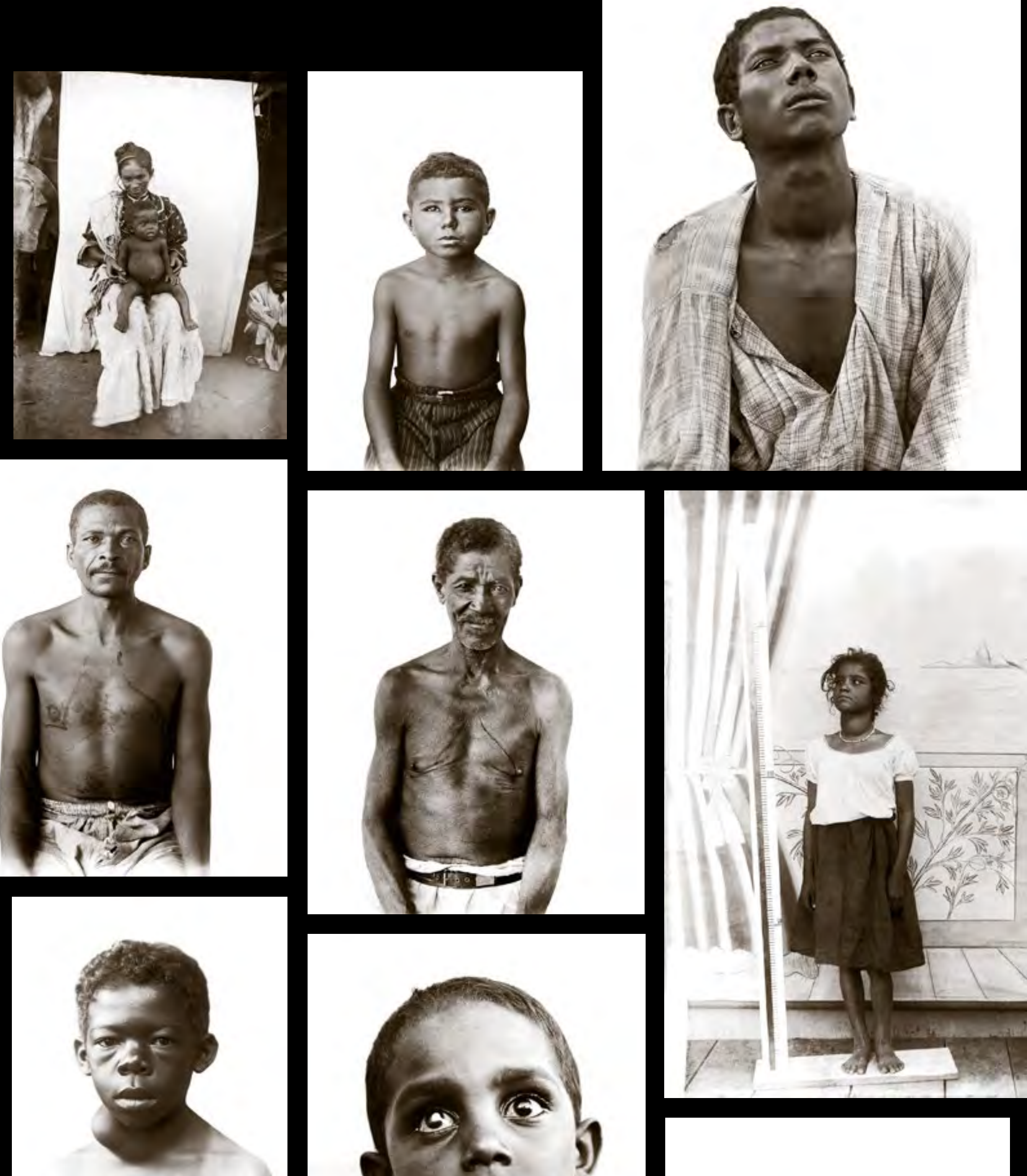

Casos descritos como portadores

da doença de Chagas

Acervo Casa de Oswaldo Cruz

Cases described as carriers of Chagas disease
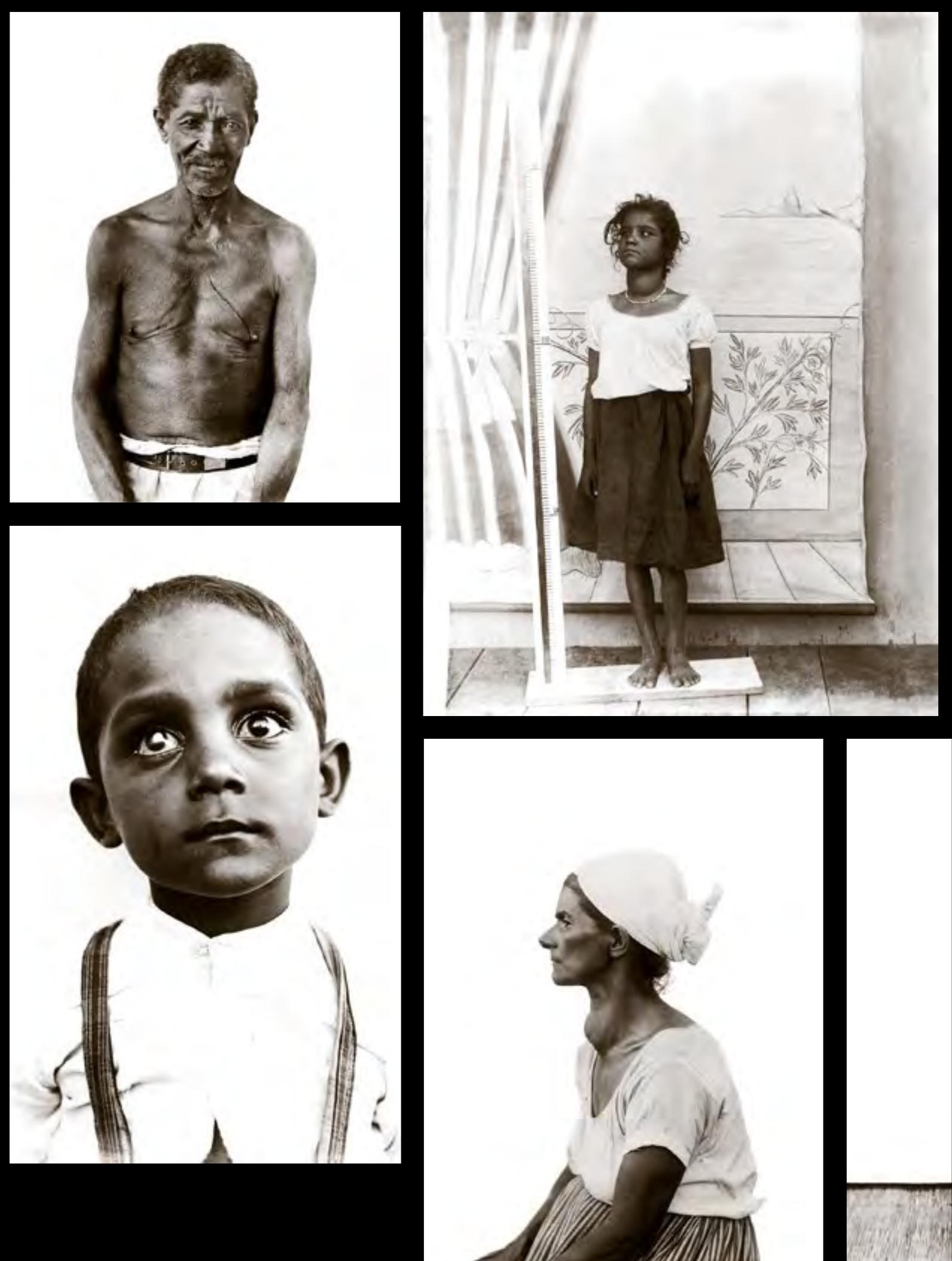


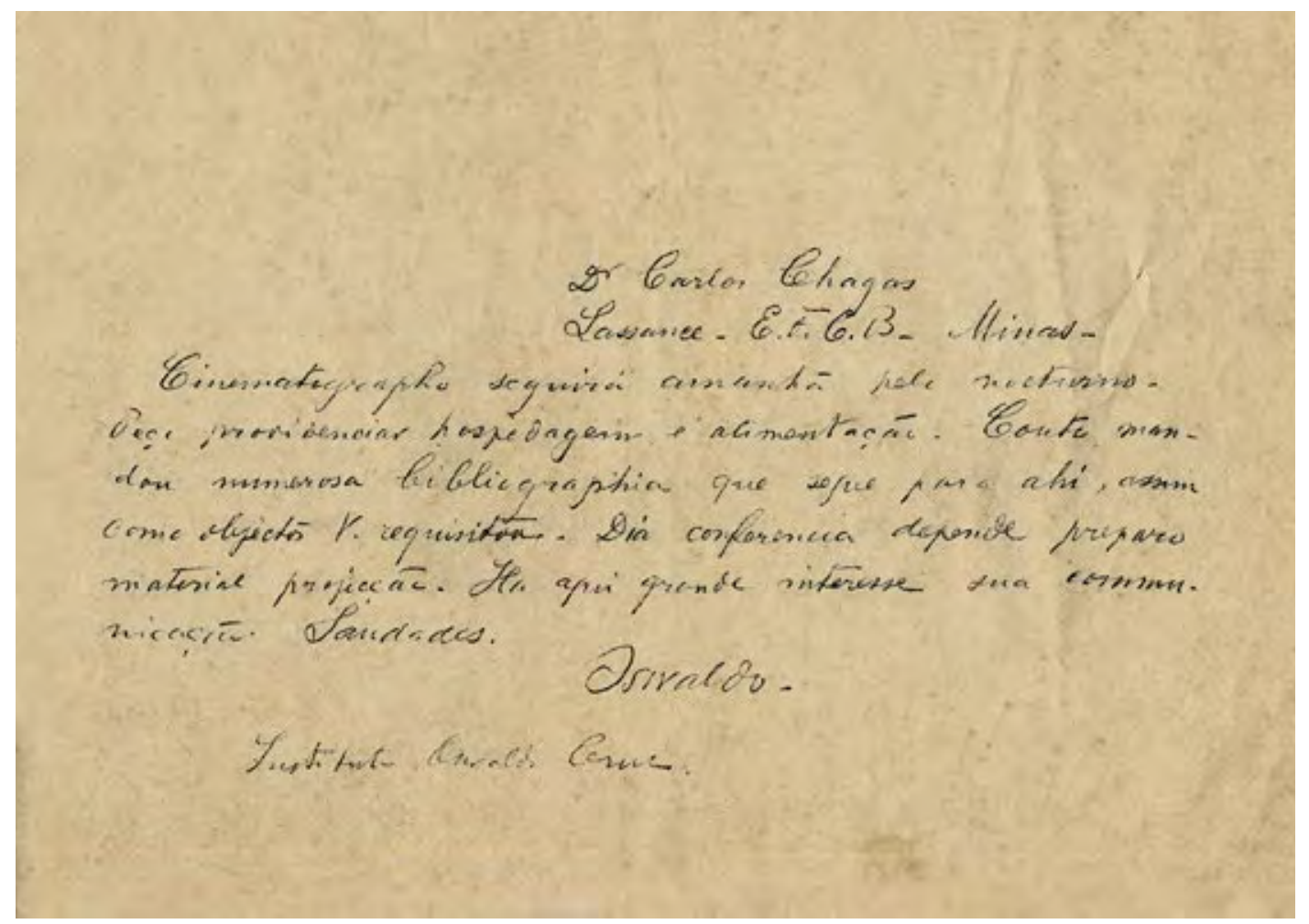

\section{MOLESTIA "C.ARLOS CHAGAS"}

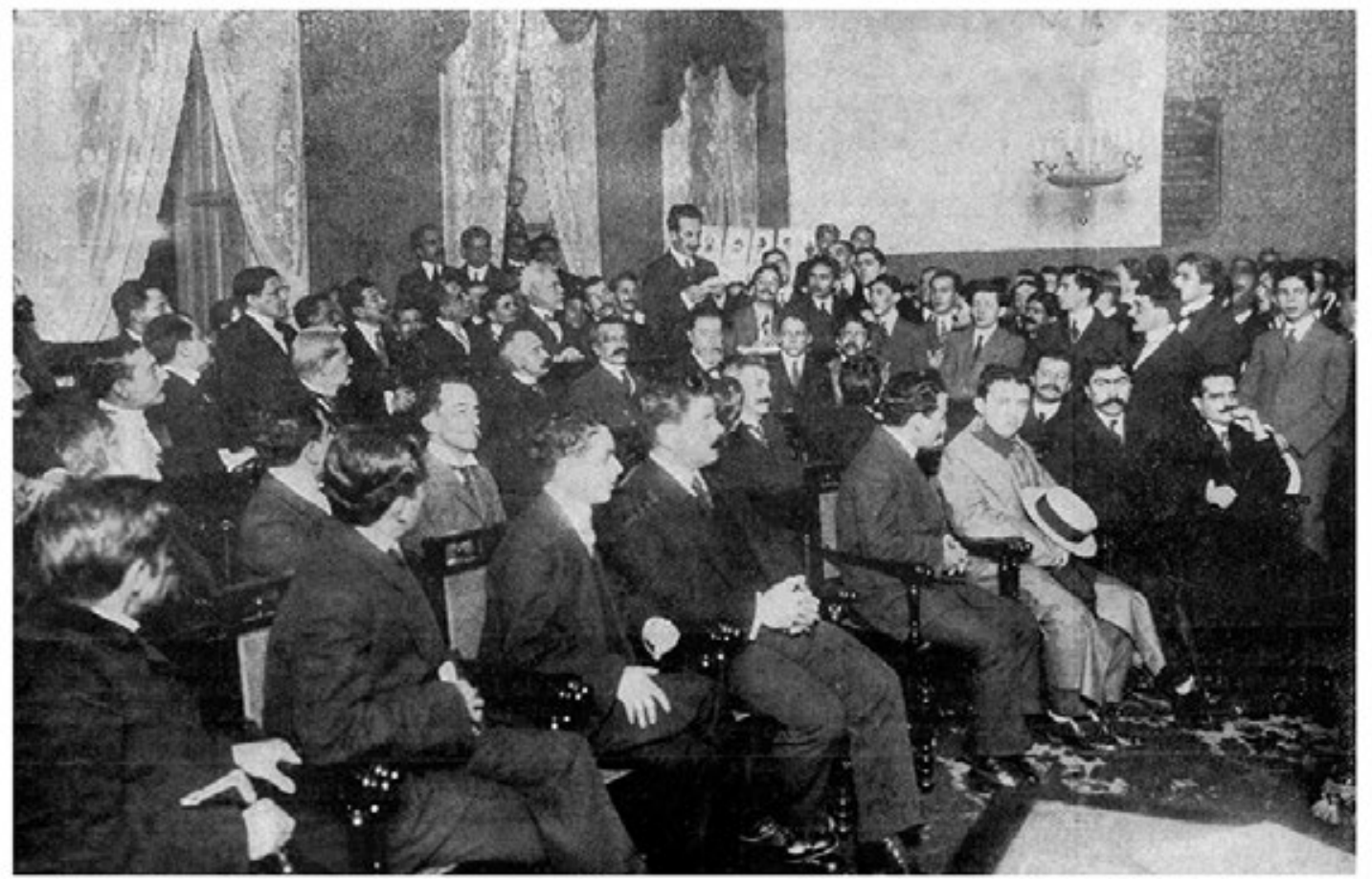

O Dr. Carlos Chagas, lendo a sua conferencia na Academia Nacional de Medicina sobre a đcscobcrta da molestia que tem - seu nome e que e preduzida por uma especie de carrapato a que chamam barbeiro - molestia terrivel que ataca geralmente os que residem em casas de taipa, cobertas de sage, isto é, grasule parte da populaçáo pobre do interior dos Estados. Essa conferencia feita na prescnça do presidente da kepublica e de numeroso e selec:o auditorio fol illustrada com projeçóes luminosas e causou profunda impressão.

Telegrama de Oswaldo Cruz a Carlos Chagas sobre o envio de cinematógrafo para Lassance, a fim de preparar imagens a serem apresentadas na Academia Nacional de Medicina. Rio de Janeiro, 1910 Acervo da Casa de Oswaldo Cruz

Telegram from Oswaldo Cruz to Carlos Chagas about dispatching a filmmaker to Lassance to capture images for presentation at the National Academy of Medicine. Rio de Janeiro, 1910

Moléstia 'Carlos Chagas'

OMalho, 12 ago. 1911

Segunda conferência de Chagas na Academia Nacional de Medicina Acervo Fundação Biblioteca Nacional

"'Carlos Chagas' Disease"

O Malho, Aug. 12, 1911

Chagas's second conference at the National Academy of Medicine 


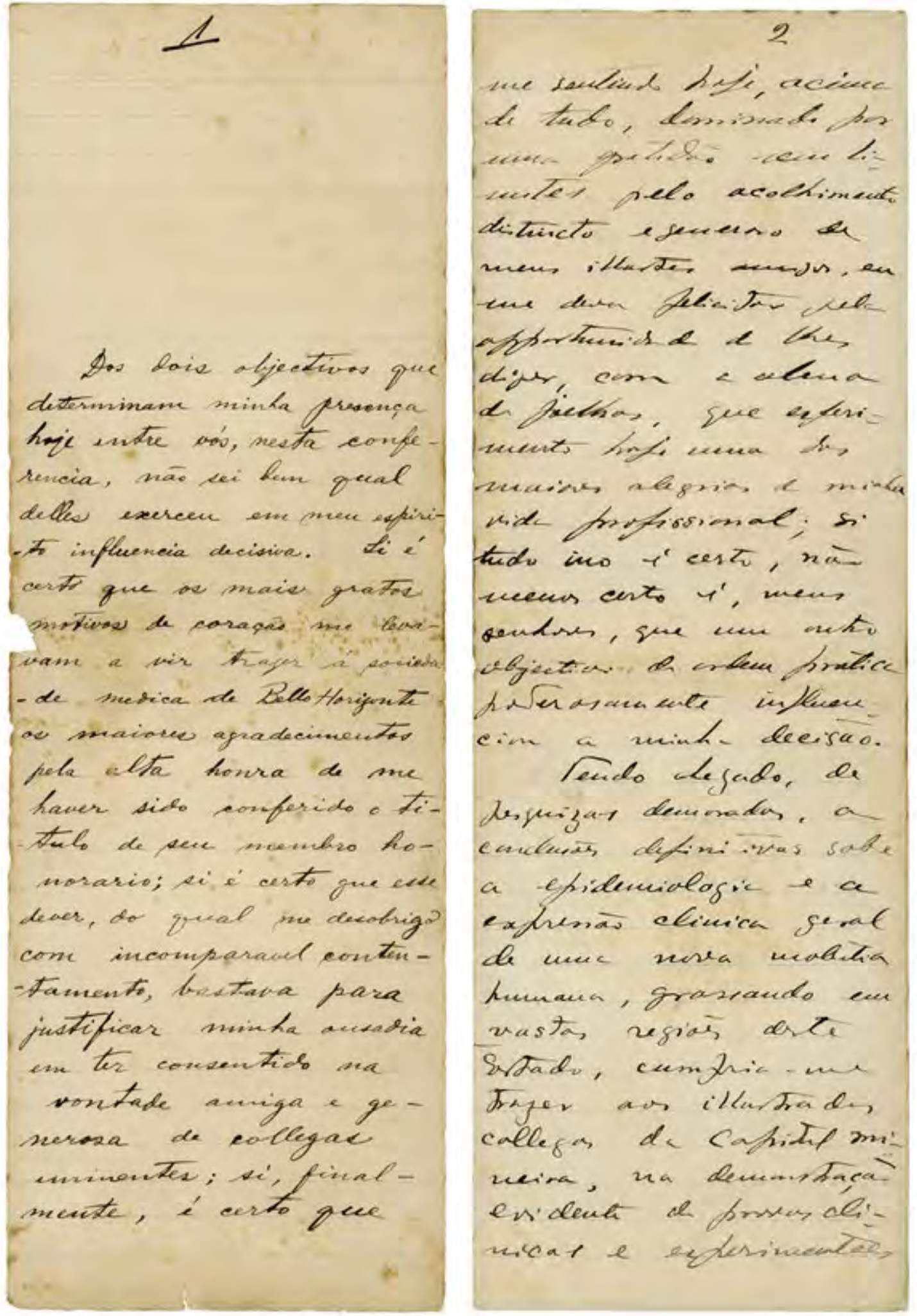

Calcule (...) quais são os resultados sociais de semelhante flagelo, no nosso país. É dever patriótico divulgar essas noções pelo Brasil inteiro, que deve estar alerta contra esse inimigo terribilíssimo!

Carlos Chagas

Just calculate (...) the social consequences of such a scourge within our country. It is our patriotic duty to disseminate these notions across all Brazil, which must be on its guard against this most terrible enemy! Carlos Chagas

Folhas iniciais de manuscrito da conferência proferida em 1911 por Carlos Chagas em Belo Horizonte Acervo Casa de Oswaldo Cruz

First pages of the manuscript of Carlos Chagas's conference in Belo Horizonte, 1911 


\title{
NOVA ENTIDADE MORBIDA DO HOMEM
}

PELO

\author{
Dr. CARLOS CHAGAS.
}

Reimpresso do * BRAZIL MEDICO * N. 43 de

15 de Novembro de 19 ro.

RIO DE JANEIRO - MANGUINHOS

66

1911

Separata de trabalho publicado por Chagas no

Brazil-Medico, relativo a sua primeira

conferência na Academia Nacional de

Medicina, realizada em outubro de 1910

Acervo Casa de Oswaldo Cruz

Reprint of Chagas's first conference before the

National Academy of Medicine, in October

1910, published in Brazil-Medico 


\section{A DOENGI DE CARLLS CHAGAS|}

Ưma sessão memoracel na Academia Nacional de Bietheiua

(....au Brésil, certaines sources qui donnent le cot. rie, $n$ out plits d'action de ce gene, lorsiquelles arrivent canalisćes dans la vil. le"... - Bozviez, Géogra. phic Médicals.)

Todos os que assistiram, e era legiáo - auditorio, á sessáo da Academia Nacio nal de Medicina, no set salẫo do Syllo geu Brazileiro, năo puderan reprimir a maior expressăo de tristeza, reconliecen do, pelas projecçōes luminosas e pela fita cinematographica que illustruram a demonstraçâo scientifica do Dr. Chagas, que ha, em una vasta zona central do Brazil, "m arande flagello, inclemente como patudisno de certas regiōes amazonicas, cruel como a febre amarela ora felizmente banida desta cidade. Aquella procisșio de desgraçados, que só o cinematogratiho podia nos deixar apreciar na sua vida actual; aquelle bando de infelizes, que vivem sofírendo ou nascem morrendo, sio as victimas de uma endenta, cuja causa arimada Carlos Chagas desvendou, e que todo o mundo scientífico confirmou e applaudiu.

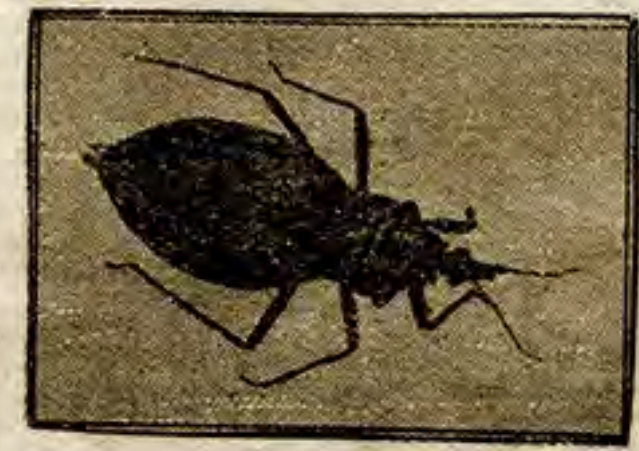

BARBEIRO

Inoculador da docnça

A doença de Carlos Chagas

O Paiz, 31 out 1910

Trecho de reportagem de Ismael da Rocha sobre a sessão da Academia Nacional de Medicina em que Chagas apresentou seus estudos sobre a

tripanossomíase americana

Acervo Casa de Oswaldo Cruz

"Carlos Chagas's disease"

O Paiz, Oct. 31, 1910

Excerpt from an article by Ismael da Rocha on the session of the National Academy of Medicine in

which Chagas presented his

studies on American trypanosomiasis

Um terrivel flagello que assola os sertões centraes do Brasil [trecho]

A Imprensa, 6 ago. 1911

Acervo Casa de Oswaldo Cruz

"A terrible scourge lays waste to Brazil's central hinterlands" [excerpt]

A Imprensa, Aug. 6, 1911

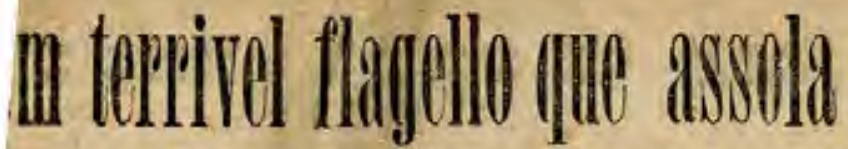
as sertices pentraers do Brasil

Uinas, Bahia, Goyaz, Mato-Grosso e parte de São Paulo presas do horrivel morbus

\section{Entrevista com o dr. Carlos Chagas, o sabio descobridor do temivel microbio}

Aquella Avenida Izabel de Pinho, lar-1 . - A distribuiç̌o geographica da moles.

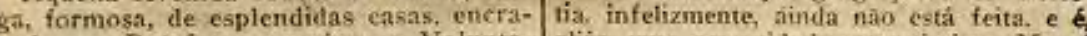
vadis em Botafogo, proximo a Volunta- alias, tma necessidade argentissima. Mas é rios, tem, no set1 numero 21 , a atoradia muito vasta a zona coutaminada: mais de de um dos mais eminentes brasileiros, o um terco de Minins. grande parte de Goyaz dr. Carlos Chagas. Este conhecido medi- e Mato Grosso, o sul da Bahia, e talvez co e scientista patrio, salbio bacietiolo- 8 . Paulo. Nas souals contaminadas - eis gista, vai para tres annos descobriu o mi- a tristissima verdacle - a populaçá inteire crobio de uma molestia que $e^{\text {a }}$ a uniea que

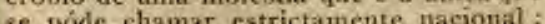
se póde chamar estrictamente nacional : e a "Sehizotripanose de Schizotripanum, que e o microbio que the es causa. Este é o nome scientifico, mas 3 denominaç̄o pratica \& "thyroidite parasitaria". sendo gue nos circulos medicos de uso appelíidal-a "molestia de Chagas", em gloria ao set benemerito investigatior:

O dr. Carios Chagas estava felizmente O dr. Carios Chagas estays for

Fez-nos conduzir á sala de visitas, que arranjadia cont arte e boni gosto.

- Dr. Chagas, sabendo que vai fazes uma conferencia no sablatio...

- Náo, a minha conferencia fícon transferida para segunda-feira.

Como salic, jă, sobre o assumipto, fiz, ha mezes uma conferencia na Academia de Medicina.

Foi apenas un ligeiro eshoco clinico Foi apenas un ligeiro estaco clinico logares infeccionados onde passei cerca logares infecciemados onde passei cerca
de 8 mezes estudando, e tive ocesisia de de 8 mezes estudando, $e$ tive occasiaso de
ohter novos conlecimentos, porque sáo infinitas as faces queapresenta essat molestia. Tem constantemente para o estudioso campo vastissimo de interesse sempre novo.

$A$ conferencia que agora vou fazer ${ }^{2}$ um complemento da primeira e desta vez com demonstraços praticas, gracas ao com demonstraçoes praticas, gracas an

elemento elinico que trouxe de Mmas.
$O$ que irei dizer segunda-feira sera. pois, um resumo geral da parasitologia da molestia $e$ da cliniea

$\mathrm{E}$ encararei o assumpto tambem no ponto de vista social, mostrando a praticahilidade de meios applicaveis de prophylaxia.

Illustrarei a seseão com novas projeIllustrarei a sessăo com novas proje-
ceóes luminosas e nova fita cinematographica de casos clinicos.

- $\mathrm{O}$ doutor trouxe alguns doenies. - Sim. 14 doentes das principaes fór. mas clinicas.

Nesta occasiăo entrou pela sala uma crianca de pelle escurecida e cabellos de caboclo.

de caboclo.
-Olhe, este $\varepsilon$ um dos atracalos da - Olhe, este \& um dos atacalos
molestia, disse-nos o dr. Chagas.

De facto, a crianca êmpletamente aplrasica e, si bem tenha 8 asyos de ida. de, nāo apparenta mais que um menino de cinco.

Tem um ofhar maito vivo, vinha rodeada de brinquedos, c fazia carinhos as dr. Chagas.

dr. Trouxe-o conmigo, continuou este. porque é muito intelligente.

porque muito intelligente. Mudos. - Nāo nos poderia o dontor dar umas
idés, geraes que fossem, sobre a moles tin?

- Pois năo. O parasita ten localiza-

- Eb antes do doutor, ninguem tínha, stquet, noticia deste flagello?

- Ninguem, absolutamente

- Cabe-lhe, pois, inuegavelmente a glor...

Nĩo, interrompeu mokiesto o grande medico, cabe-me apenas at sorte de ter sido a primeiro. E foi interessante o facto da minhat descoberta. $O$ senhor sahe que a molestia se transmitte por meio do "barbeiro", que é am insecto que vive com o homem a habita as casas cuja construcçáo é primitiva, out mal cniclakla, como as da poptalaça pobre e de muitas hatitacues em nossos Estulos. Pois bem, nos intestinos do "barbetro" fui encontrar um parasita desconhecido. Fiz picar, entấ, animaes do Jaloratorio, que adoeceram. Dahi comciei mislias pesquizas.

$\mathrm{Im}$ Minas pude verificar que, em todas as casas onic havia o "barbeiro", as pessoas apresentavaun aspecto doentio. Estudando o sangue das pessoas gute offereciam os typos mais agudos da molestia, nellas fui encontrar exactamente o selisofrifonam. Dahi por diante tenho de continuo estudado esta molestia, retdadeiramente terrivel. e que, para o estudioso tem sempre aspectos novos, nois $\hat{\varepsilon}$, talvez, mais variadat que a syphilis, que ế, aliás, do mesmo grtipo zoologica da thyroidite parasitaria de que estamos falando.

- I. a cura deste horror?

- Ah! por emguant, nenhum meio theraveutico se conhece com efficacia, pelo menos, no periodo agudo... A prophylaxia, sim, tenho-a estudado com vantacem e a clla me referirei na proxima conferencia de segunda-feira. Como meio de cura, já mpregtei o " 606 ", mas sem resultado. Em gualđade de condiçốes com a molestia de ue the falo, so existe a molestia do somno, ná Árica, e que já está muito bem estudada pelos europeus.

Aliăs, a molestia brasileira tambem tem preoccupado o Velho Mundo, cujas revistas echnicis ou leigas tèm dedicado columnas inteiras a "schizotripanose".

Tem mesmo preoccupado mais a Europa que o nosso meio, não obstante a neninuma diffictldade que encontrei em me fazer acreditado. Nas regióes flagelladas, todos os medicos immediatamente acolheram,com grande curiosidade e interesse, o resultado de minhas experimentaçöes, Sim, porque a causa ć de uma horrivel evidencia e estí udo perfeitamente estudado, tanto que nảo temo a minima contestaçầo a tudo quanto tenlio dito e vou dizer.

Nesta ultima viagem, commigo foi una conmissăo doutissima, composta dos drs. Couto. Anstregesilo aswaldo Crinz, que Couto, Ausiregesilo e Oswaldo Cruz, que o mea mestre. Viram mass de 150 doentes 
CORRETo DA MANHa - Sexta-feira, 11 de Agosto de 1911

\section{A "doença Carlos Chagas"}

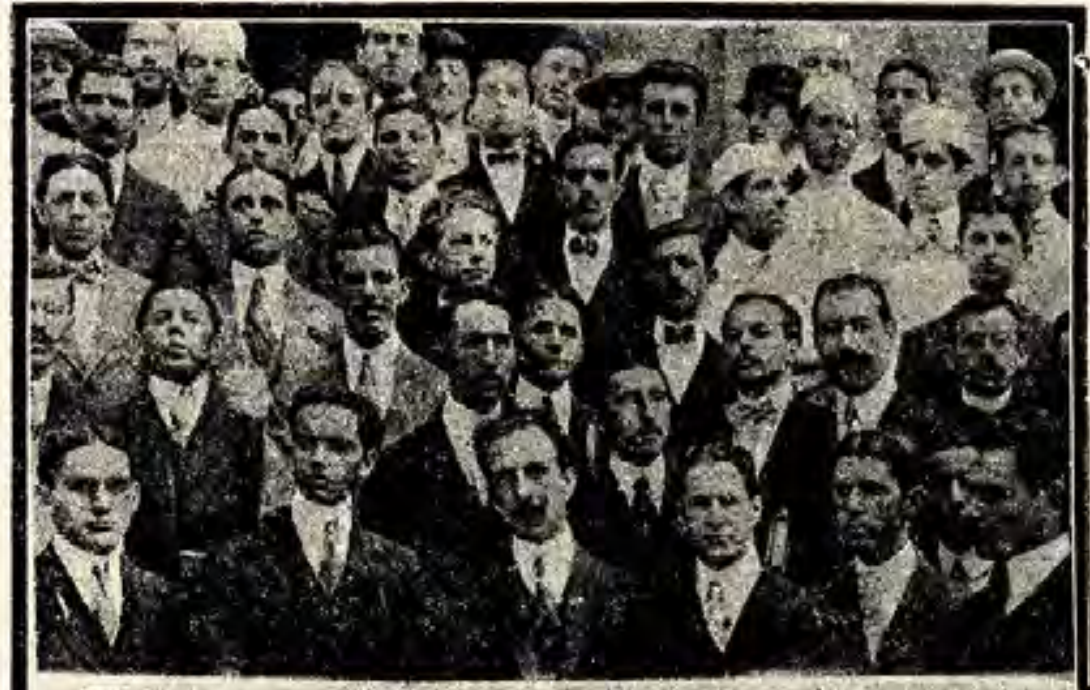

\section{A sessão de hontem}

no hospital da Misericordia

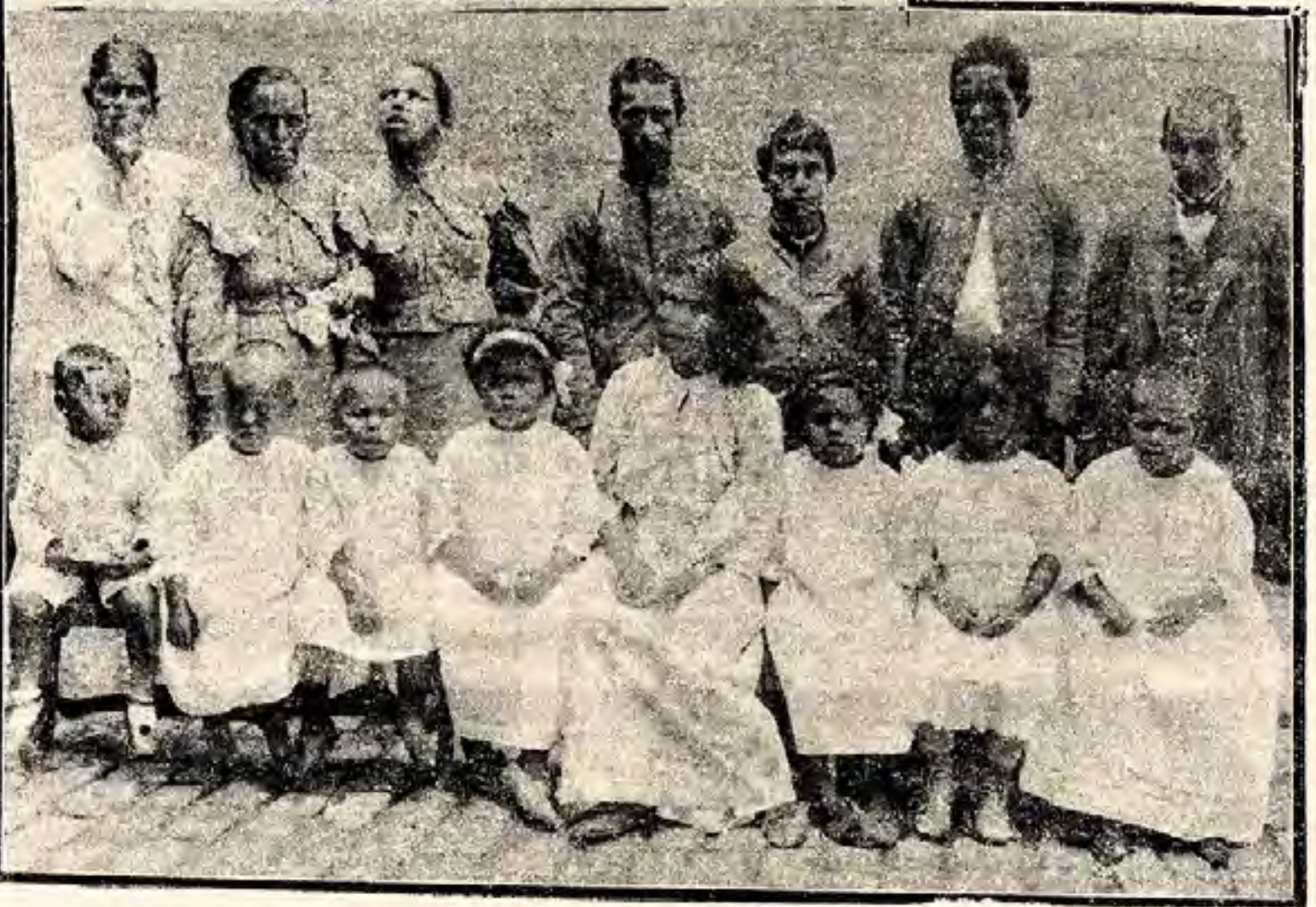

0 di. Carlus Chagre, rodeado por grande numero dos academicos que ascistiram a sun pretercio de hontem. Grupo de enfermos da edoenca Curlos Chagas

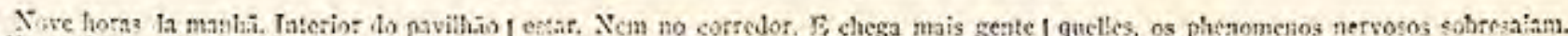

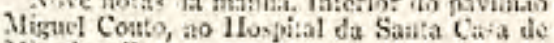
Miferisontit. Aingutem se pide nexe:. Teo: que um for-

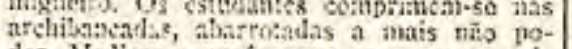
der. Misitsos o professonsts cone ervam-se de

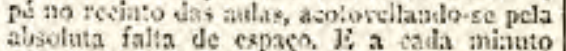
qtis se ession, é mais ketate ntic chega. Vialros

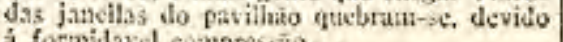

a formidavel eompressio...
is mais gente. ji is portas ninguem póde Questes, a fórma cardiaca dominara; na-

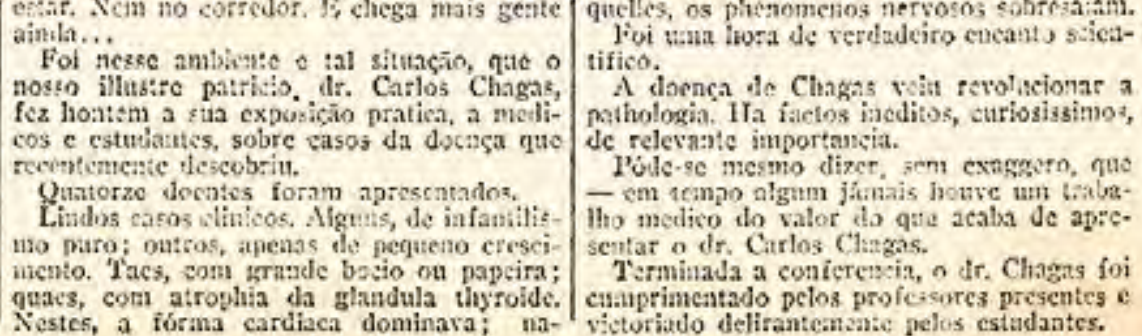




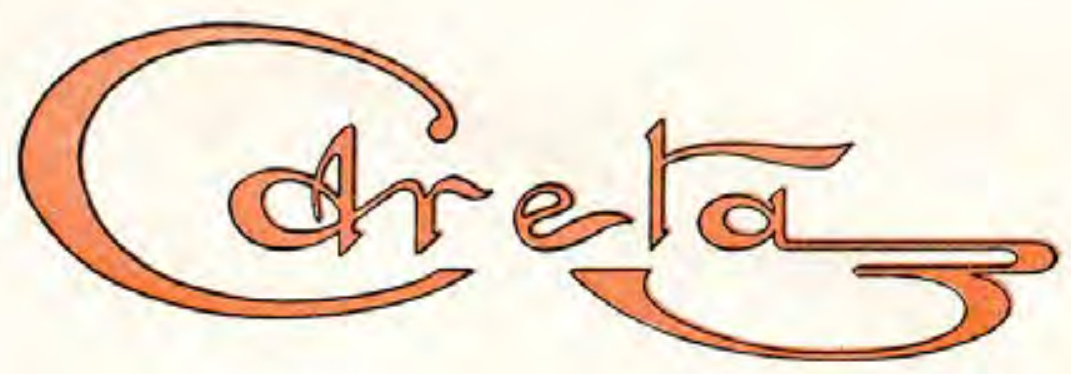

\section{REDACÇÃO E OFFICINAS: RUA DA ASSEMBLÉA, 70 - RIO DE JANEIRO}

\author{
ASSIGNATURAS \\ ANNO ...... $15 \$ 000$ | SEMESTRE . . . \$ \$ \$ $\$ 000$
}

NUMERO AVULSO

CAPITAL. .... 300 Rs. | ESTADOS. ... $400 \mathrm{Rs}$

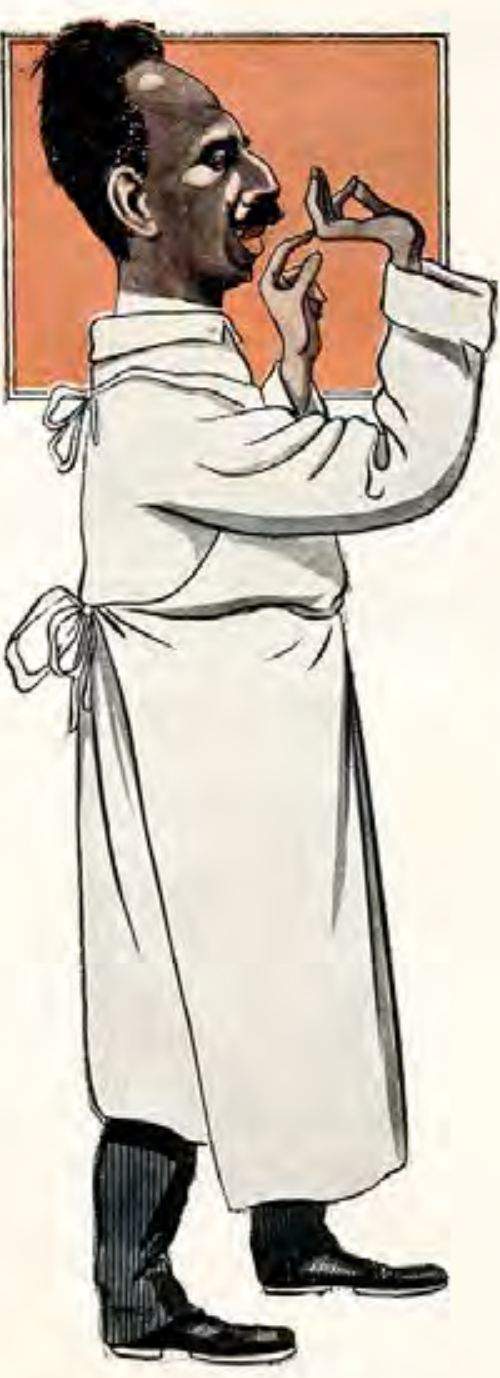

Dr. Carlos Chagas

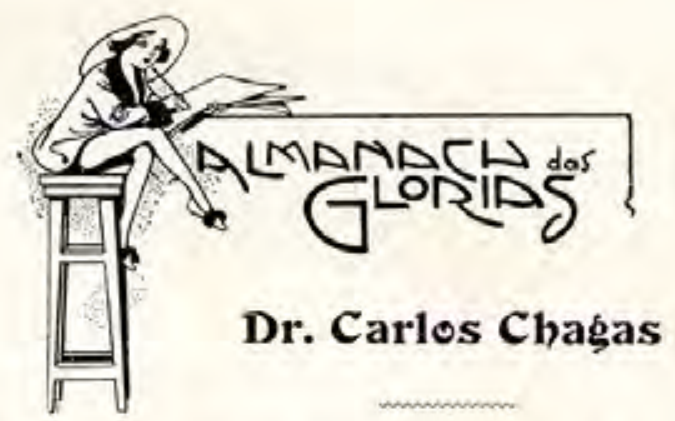

O Dr. Carlos Chagas, do nosso nacional Instituto de Manguinhos, é o benemerito descobridor da molestia que recebeu o seu nome na pia baptismal da sciencia.

A doença de Chagas, a thyroidite parasitaria, atacando a quinta parte das nossas indolentes populacões sertanejas, transmittida pelo abundante insecto denominado barbeiro, atrophia a glandula thyroide $\mathrm{e}$ produz, além de outros muitos males, o papo, o idiotismo, a desvirilisação, a paralysia geral.

O grande scientista, com a tenacidade modesta peculiar aos sabios, descobrio as causas e os meios de transmissão, o desenvolvimento $\mathrm{e}$ as modalidades, os effeitos $\mathrm{e}$ as consequencias, bem como o tratamento dessa, em verdade, terrivel molestia.

Emquanto, por entre alas de povo deslumbrado, os generaes, fulgurando na pompa dos seus uniformes, exercitam as guapas hostes destinadas ao serviço patriotico da morte, e os artistas recebem retumbantes applausos e todos, alegres ou tristes, somos vistos no turbilhão ondeante da vida, o homem de sciencia olvidado e invisivel, trabalha $\mathrm{em}$ silencio obscuro; jámais a sua gloria se reveste de aspectos brilhantes e nunca é proclamada com enthusiasmo no delirio das expansões populares, e quando, por ventura, o exito completo não é o remate das suas pesquizas, o sabio desapparece do mundo sem que ao coração dos homens chegue o conhecimento de seus longos esforcos improficuos. Sabio, merecedor de todas as glorificaçốes, o benemerito Dr. Carlos Chagas continúa a ser um distincto moço obscuro. 


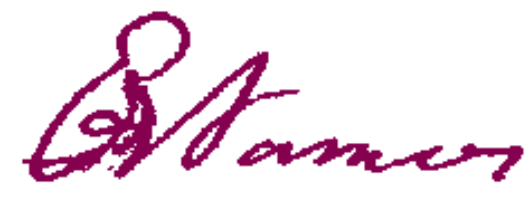

$20<$
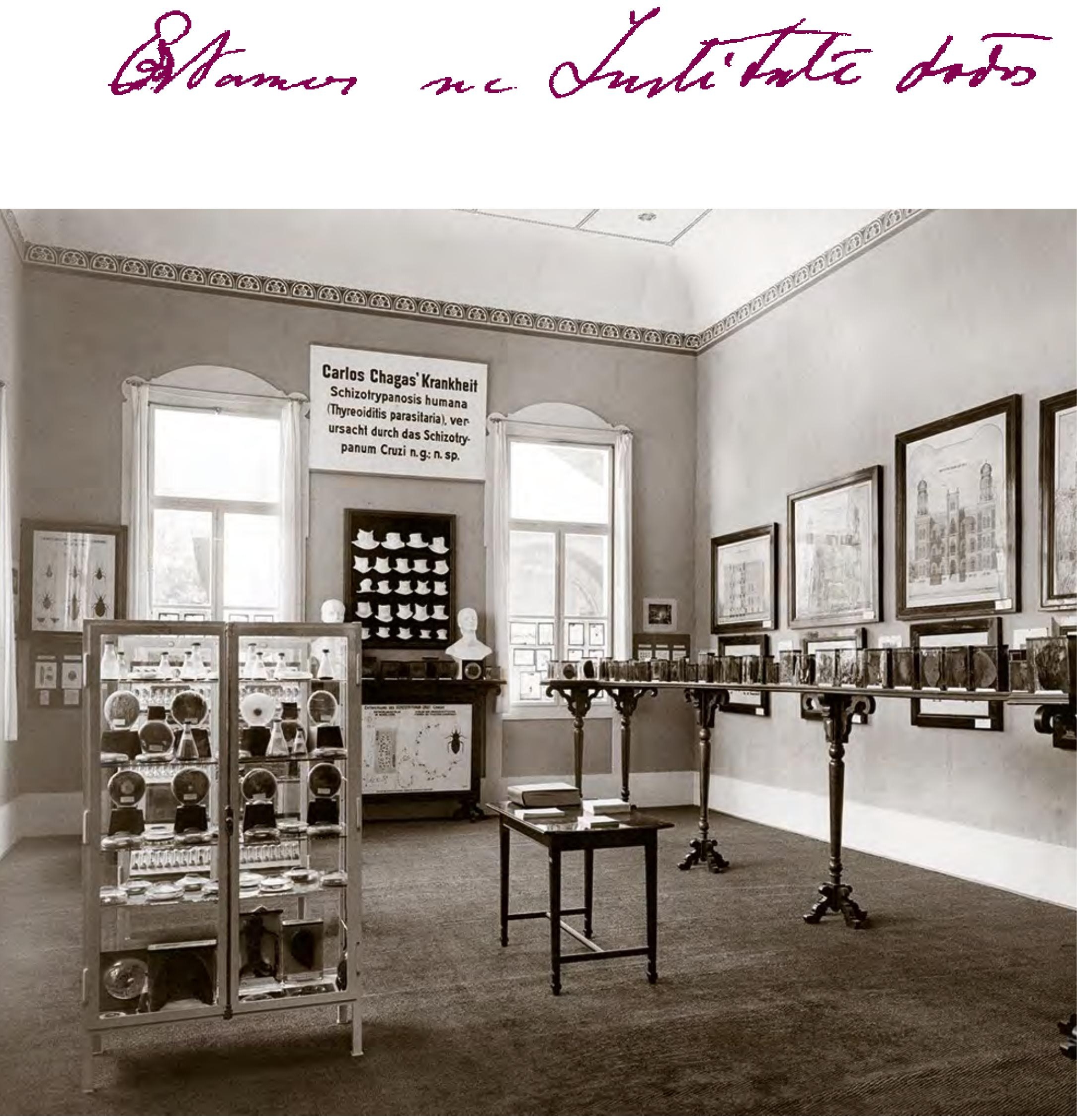

Materiais relativos à doença de Chagas em sala do pavilhão brasileiro na Exposição de Dresden, Alemanha, em junho de 1911

Acervo Casa de Oswaldo Cruz

Materials about Chagas disease on display at the Brazilian pavilion at the Dresden Exhibition, Germany, June 1911

Pavilhão brasileiro na Exposição Internacional de Higiene e Demografia realizada em Dresden

Acervo Casa de Oswaldo Cruz

Brazilian pavilion at the International Exposition on Hygiene and Demography, held in Dresden 


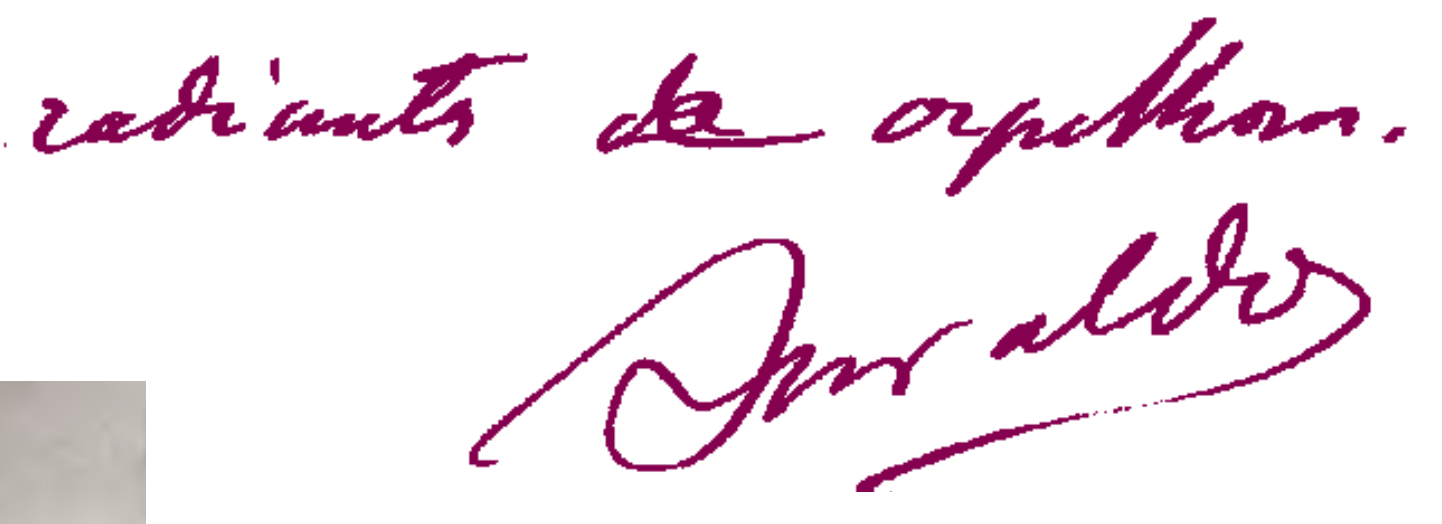

All of us at the Institute are bursting with pride Oswaldo

O material que levamos é abundante e importante: a moléstia de Chagas vai prender a atenção; levamos preparados, peças anatômicas, fotografias, moldagens em gesso, bustos de doentes.

Oswaldo Cruz

We are taking an abundant amount of important material: Chagas disease will capture attention; we are taking preparations, anatomical parts, photographs, plaster molds, busts of the ill.

Oswaldo Cruz 


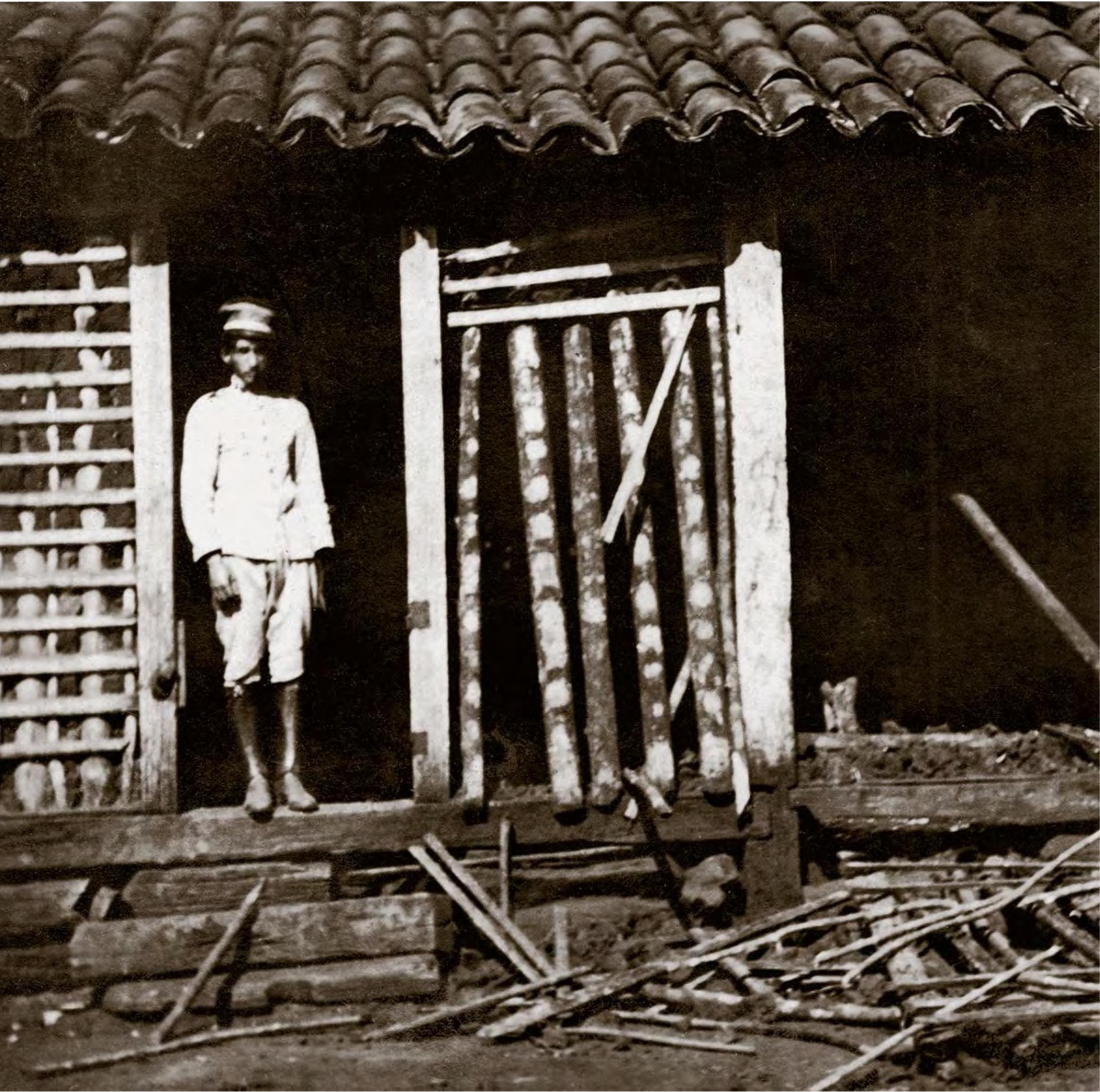

Demolição de casa para combate ao barbeiro. Jataí, PR, 1919. Para Chagas, o combate à

"doença do barbeiro" deveria ser feito pela melhoria nas habitações rurais. Em 1918, o

Serviço de Saneamento Rural do Paraná foi pioneiro em estabelecer normas para a

construção de casas visando a impedir a proliferação de barbeiros. Os inseticidas foram

utilizados somente a partir da década de 1950

Acervo Casa de Oswaldo Cruz

Razing a house in the battle against the barbeiro. Jataí, Paraná, 1919. For Chagas, the

"barbeiro disease" should be fought by upgrading rural housing. In 1918, the state of Paraná's

Rural Sanitation Service was the first to enact standards on home construction with

the intent of preventing the proliferation of barbeiros. It was only in the 1950s that insecticides

came into use 


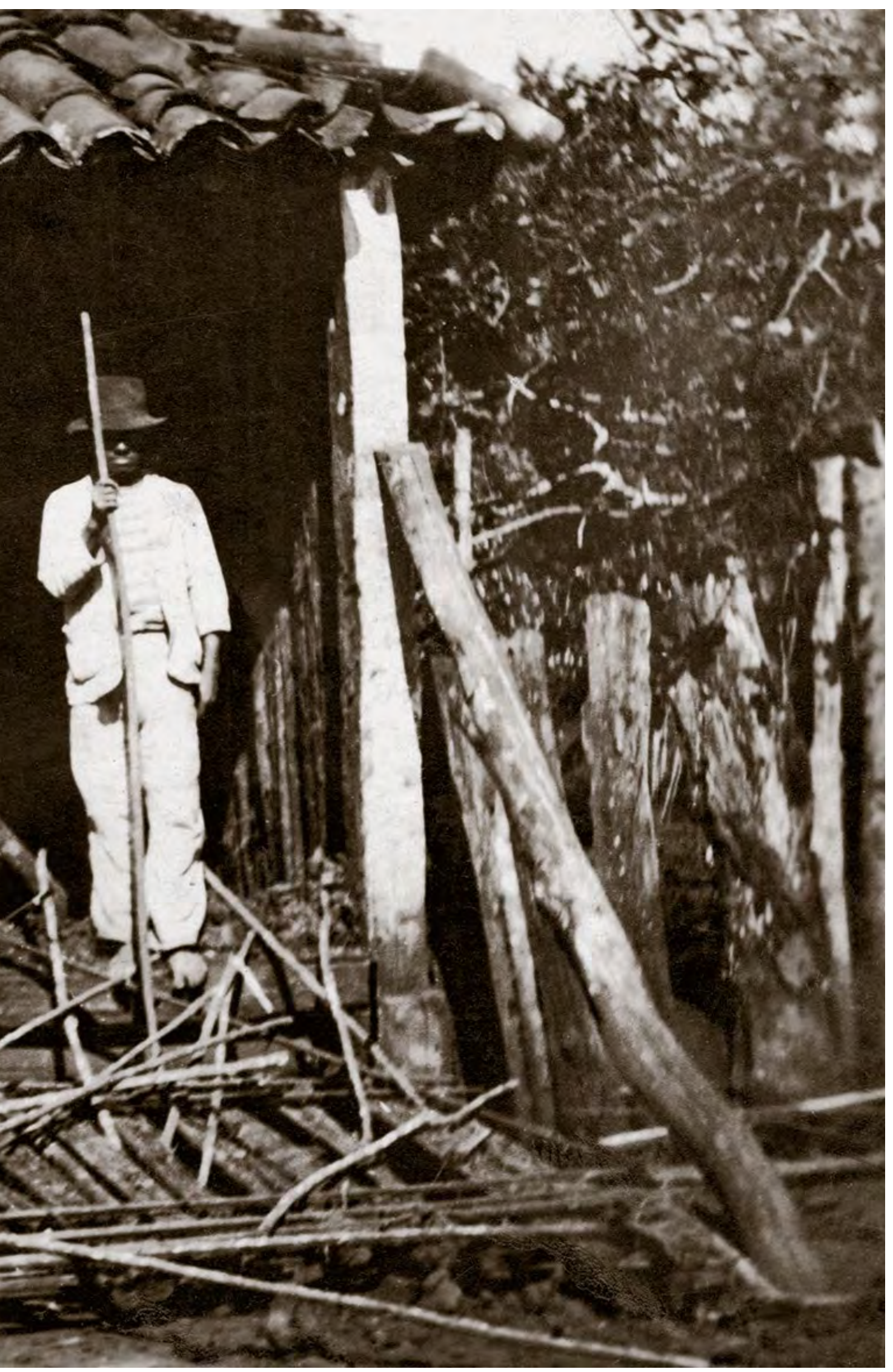

Poder-se-há, na higiene pública, encontrar meios eficazes de atenuação do mal? Acreditamos que sim, se tal problema, seguramente problema de Estado e de humanidade, se tornar preocupação de um estadista cientificamente bem orientado.

Carlos Chagas

Will it be possible, within public hygiene, to find efficacious ways of attenuating this affliction? We believe so, if this problem-most surely a problem of the State and of humanity - becomes the concern of a scientifically welladvised statesman.

Carlos Chagas 


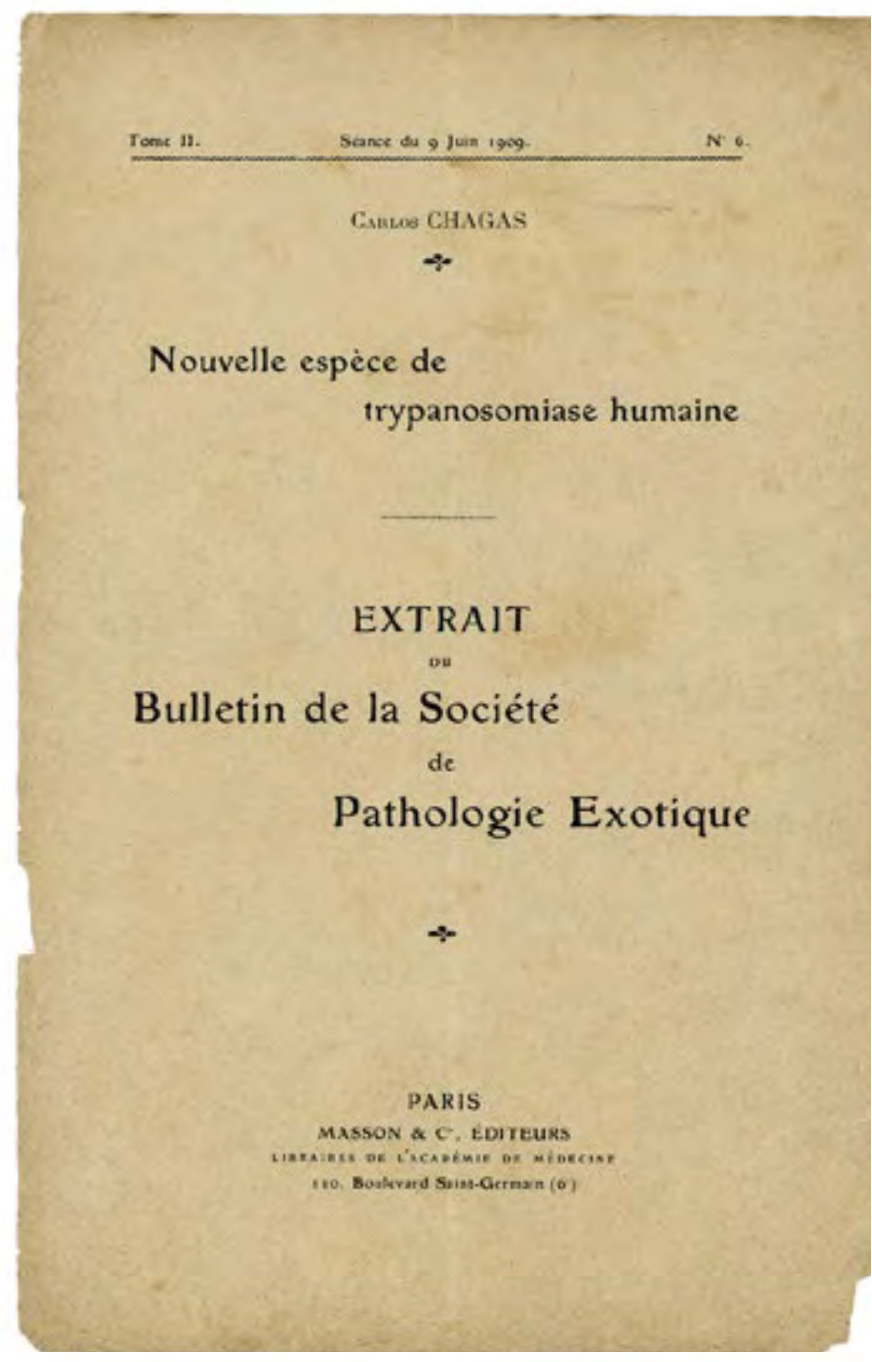

\section{NOVA ENTIDADE MORBHA DO HOMEM} neto

Dk. CARLOS CHAGAS.

trypanosomiase humaine
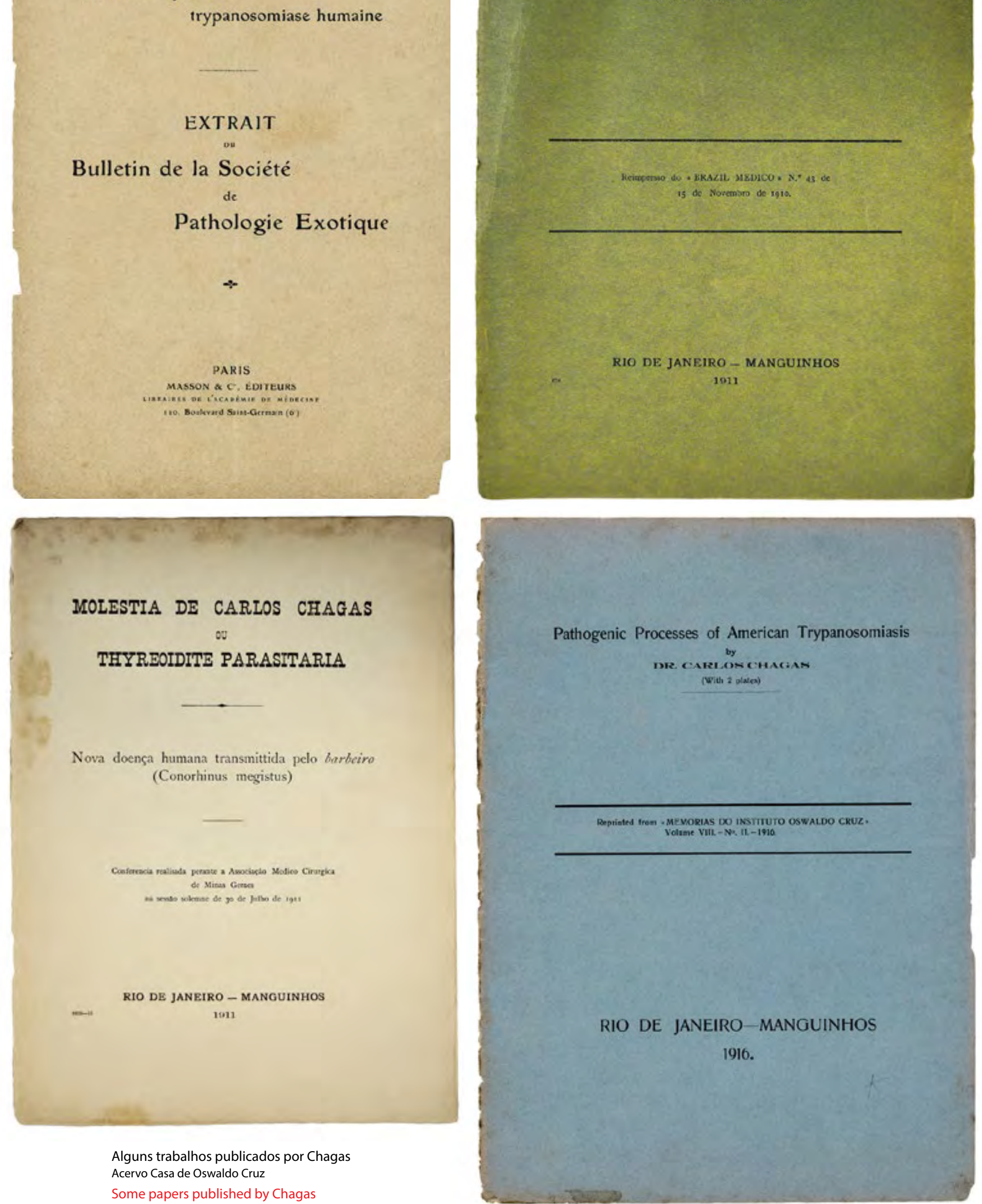

Acervo Casa de Oswaldo Cruz

Some papers published by Chagas 
ASPECTO CLINICO GERAL DA NOVA ENTIDADE MORBIDA PRODUZIDA PELO SCHIZOTRYPANUM CRUZI.

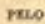

Dr. CARLOS CHAGAS.

Reimpareso do . BRAZIL. MEDICO, N* 19 de is de Jullho de rg10.

RIO DE JANEIRO - MANGUINHOS

1910

\section{ARCHIVES \\ oEs \\ NALADIES DU CCER \\ DES VAISSEAUX ET DU SANG

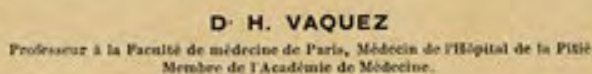 \\ racadkmie do scodocine.}

\section{SUR LES ALTERATIONS DU CCEUR DANS LA \\ TRYPANOSOMIASE AMÉRICAINE \\ (MALADIE DE CHAGAS) \\ 10 Profesanue CHAOAs (Rio-de Janeiro)}

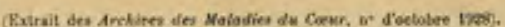

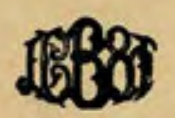

PARIS

LIBRAIRIE J,-B. BAILLIBRE ET FILS

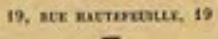

\section{Amerikanische Trypanosomiasis} (Chargasmohe Krankheit) Kurso atsologisohe und klinimohe Botrachtunges.

\section{Dr. GaRLOB CRAGas}
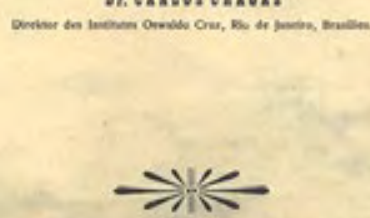

1925

\section{FORME CARDIAOUE DE LA TRYPANOSOMUASE AMÉRICANE}

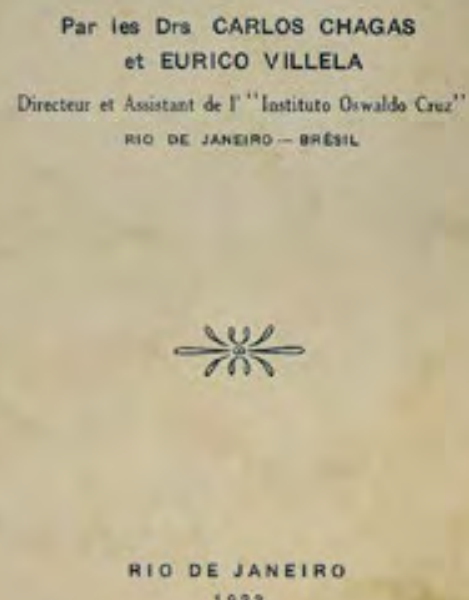

1923 